\title{
A Derivation of Factors Influencing the Successful Integration of Corporate Volunteers into Public Flood Disaster Inquiry and Notification Systems
}

\author{
Chia-Lee Yang ${ }^{1}$, Ming-Chang Shieh ${ }^{2,3}$, Chi-Yo Huang ${ }^{4, *}$ and Ching-Pin Tung ${ }^{3}$ \\ 1 National Center for High-Performance Computing, Hsinchu 300, Taiwan; joy.yang@nchc.narl.org.tw \\ 2 10th River Management Office, Water Resources Agency, Ministry of Economic Affairs, Taipei 106, Taiwan; \\ mcshieh59@gmail.com \\ 3 Department of Bioenvironmental Systems Engineering, National Taiwan University, Taipei 106, Taiwan; \\ cptung@ntu.edu.tw \\ 4 Department of Industrial Education, National Taiwan Normal University, Taipei 106, Taiwan \\ * Correspondence: georgeh168@gmail.com; Tel.: +886-2-7734-3357
}

Received: 15 May 2018; Accepted: 4 June 2018; Published: 12 June 2018

\begin{abstract}
Flood hazards have become increasingly common and serious over the last few centuries. Volunteers can observe instant flood information in their local environment, which presents a great opportunity to gather flood information. The information provided by individual volunteers is too much for them to truly understand. Corporate volunteers can offer more accurate and truthful information due to their understanding of the roles and requirements of specific tasks. Past studies of factors influencing the success of corporate volunteers in flood disaster are limited. Thus, this research aims to derive the factors that enable corporate volunteers to successfully integrate the flood information to help reduce the number of injuries and deaths being caused by flood disasters. This research used the information success model and the Public-Private Partnership (PPP) model to develop an analytic framework. The nature of flood disaster management problems is inherently complex, time-bound, and multifaceted. Therefore, we proposed a novel hybrid multi-criteria decision-making (MCDM) model to address the key influence factors and the cause-effect relationships between factors. An empirical study in Taiwanese public flood disaster inquiry and notification systems was used to verify the effectiveness of the proposed methodology. The research results can serve as guidelines for improving the government's policies and the public sector in the context of corporate volunteer involvement in flood disaster inquiry and notification and in relation to other natural and manmade disasters.
\end{abstract}

Keywords: public-private partnership (PPP); disaster notification system; flood disaster; information system success model; multiple criteria decision making (MCDM)

\section{Introduction}

The flood hazard is the most frequent natural hazard, which accounts for nearly half of all natural disasters worldwide [1]. Since the dawn of human history, destructive floods have jeopardized settlements near rivers. In the past two decades, flood hazards have become even more destructive and dangerous due to climate change, population growth, and greenhouse gas concentrations [2-4]. Now, the global flood losses have increased worldwide, causing billions of US dollars in damages per year [5]. According to recent statistics by the United Nations [6], 157,000 people died as a result of floods from 1995 to 2015. In the same period, 2.3 billion people were affected by floods, accounting for $56 \%$ of all those affected by weather-related disasters [6]. Flood damage in the world's major coastal 
cities may top $\$ 1$ trillion a year by 2050 due to rising seas and subsiding land [7]. Apparently, the flood hazard is more dangerous compared to any other type of weather-related disasters [8].

Sustainable development can be defined as that which helps to fulfill the present needs of the world's poor without compromising the capability of future generations [9]. The societal goal of sustainable development is converted into a set of objectives-objectives for the safety and objectives for the preservation of natural functions [10]. Therefore, devastating floods, which have brought more death and suffering to humans and other living things than any other types of weather-related disasters, could be viewed as enemies of sustainable development; accordingly, systems of flood protection and management are being increasingly considered in the context of sustainable development [8].

Traditionally, flood hazard mitigation has focused on engineering methods such as construction of dikes to prevent damages and losses from flood. However, engineering methods can be extremely costly and involve construction work. Further, increasingly more flood hazard events have started to occur in urban areas due to continuous urban development in headwater regions, as well as climate change effects on river discharges and flood probabilities [11,12]. It is hard to find suitable areas that are available for dikes construction. Therefore, the paradigm of flood hazard mitigation has shifted to sustainable flood management [13], which emphasizes efficiently minimizing flood influences together with stakeholders, while considering economy, society, and environment both from short-term and long-term perspectives [14].

Sustainable flood management is a continuous process that aims to avoid or reduce the effect of flood hazards. All phases of flood management require current and accurate information. The flood disaster inquiry and notification system involves selecting, receiving, processing, and transmitting current disaster information immediately. Existing flood disaster inquiry and notification systems monitor flood hazards using sensor technologies. The collected flood hazard information varies in nature due to the adoption of different sensing technologies, for example, water gauges, seismometers, aerial sensors, satellite remote sensing technology, and others. Eye witness reports by professional staff are another traditional and still very valuable flood monitoring method for situational awareness in recent flood disasters [15]. The eye witnesses by volunteers (also called volunteered information (VI)) are playing increasingly critical roles in flood monitoring. For example, from December 2010 to February 2011, the State of Queensland in Australia experienced a series of damaging floods that led to the loss of more than 20 lives and several billion-dollar properties. The Queensland's government used VI, such as the photographs and videos provided by volunteers, to assist the mapping of the flood geographic information map. Apparently, the integration of VI with existing flood disaster inquiry and notification systems can provide valuable real-time flood information for disaster management during floods. The real-time flood information from VI can also improve hydrological modeling to help with future flood disaster management and prevention [16]. However, various challenges must be resolved before VI can be considered as a useful information source. Usually, volunteers can be divided into two categories: individuals and corporate volunteers. Individual volunteers are usually recruited from social networks or public media, where there are serious overloads and impure information [17]. In contrast, corporate volunteers may offer more accurate and timely information for flood emergency decision-making [18], but corporate volunteers are involved in volunteer activities during working hours and have the responsibility to provide quality flood information.

Corporate volunteers can offer a great opportunity to play a more dominant role by collaborating to enhance the response effectiveness of flood disasters for the community. The study of corporate volunteers has grown quickly in the last decade, especially in Europe and North America [18]. While the literature provides valuable insights into how corporate volunteers contribute to disaster relief, there is a need for a more comprehensive understanding of how to build long-term partnerships with the public sector, corporations, and information technology providers [19]. Most existing research has focused on the effectiveness of individual volunteers recruited from social networks or the development of sensor technology for flood disasters. Very limited prior works have tried to analyze possibilities or factors influencing the integration of corporate volunteers into the public disaster 
management system from the aspects of corporate volunteers and flood disasters. Thus, the analysis of factor dimensions influencing the integration of corporate volunteers into a disaster management system is very important. The identified factors can be used to evaluate and select strategies to improve corporate volunteers' effectiveness and efficiency in the inquiry and notification of flood disasters.

This research aims to identify the factors enabling corporate volunteers to respond to inquiries and notify the public disaster management system of flood disasters. Because flood disaster management problems are inherently complex, time-bound, and multi-faceted, involving many decision-makers, high decision stakes, limited technical information, and difficult tradeoffs, the problem involves multiple-criteria decision making. To identify the relevant factors, this research introduces a novel hybrid multi-criteria decision-making (MCDM) framework based on the Information System Success Model and the model of Public-Private Partnership (PPP) to solve the complex problem of decision-making. The Decision Making Trial and Evaluation Laboratory (DEMATEL) is used to construct the influence relation map (IRM) between factors [20]. Then, the Analytical Network Process (ANP) is used to derive the weights versus the dimensions and criteria based on the concept of the Markov chain. An effective analytic framework for integrating corporate volunteers in the public disaster management system can then be defined. An empirical study based on the integration of corporate volunteers into the public flood disaster inquiry and notification system in Taiwan is used to verify the feasibility of the proposed framework. The survey experts included water resource agency officers, information system service providers, managers from the 7-Eleven Corporation, and flood disaster notification researchers in Taiwan.

The analytic results can serve as a foundation for increasing the participation of corporate volunteers in the disaster inquiry and notification systems. The satisfaction and benefits of such systems can then be increased; thus, the costs of collecting flood information can be greatly reduced. The proposed multi-criteria decision support framework can also be used to enhance communications among various stakeholders, including the public sector, and corporate and information system providers. The analytic results can also be used to improve public-private partnerships in the field of disaster management.

The rest of this paper is organized as follows. Section 2 presents a review of flood hazards, flood disaster inquiry and notification systems, the PPP model, and the information system success model. The research methods and the MCDM framework are presented in Section 3. The empirical study on the integration of corporate volunteers into the Taiwanese public flood disaster inquiry and the notification system is presented in Section 4. Section 5 discusses advances in management practices and compares the empirical study results with past research. Finally, Section 6 concludes the paper with major research findings, contributions, and future research possibilities. The proposed decision framework has important implications for both academics and practitioners in gaining a better understanding of the factors influencing the integration of corporate volunteers into public disaster inquiry and notification systems.

\section{Conceptual Framework}

To review the current involvement of corporate volunteers in public flood disaster inquiry and notification systems and to construct an analytic framework, a conceptual framework is reviewed and summarized below. We focus on flood hazard management, disaster inquiry, and notification systems, as well as the public-private partnership and information success model.

\subsection{Flood Hazard Mitigation}

Flood hazard mitigation is a concept complicated by the social, economic, and political aspects of our environment [21]. Since flood hazards are becoming increasingly dangerous, flood hazard mitigation has become dramatically more important in recent years. To manage flood damage and risk, various flood hazard mitigation strategies have been studied. The most widely adopted strategies of flood hazard mitigation are structural and non-structural. The structural strategy comprises 
general structural engineering methods in civil engineering. Such methods are introduced to resist and mitigate the effects of floods by constructing dikes and dams, among others. In contrast, non-structural methods aim to adjust human activities and communities to mitigate flood damages through land-utilization plans, decree norms, flood warning systems, and public education for disaster preparedness [22]. Typically, non-structural flood hazard mitigation strategies are knowledge, practices, or agreement-based approaches to reduce risks and effects of flood; such strategies do not involve physical constructions [23]. Since studies based on past floods have shown that structural engineering-based strategies are not able to completely overcome flood hazards, adequate non-structural strategies can be considered to decrease the costs of flood mitigations and to further reduce the loss of life and properties [11]. Therefore, in many cases, both structural and non-structural mitigation strategies are used within a single jurisdictional flood program.

Given that non-structural flood mitigation strategies, such as risk management, are playing dominant roles, interest in non-structural flood mitigation strategies in general and flood risk management in particular is increasing [24]. Traditionally, the government plays a key role in structural flood hazard mitigation strategies [12]. Since non-structural mitigation strategies are playing a critical role in flood mitigation, the private sector can play a more dominant role by adopting more flood mitigation measures, such as the use of flood protection devices, adapted building use, or flood insurance [3].

\subsection{Flood Disaster Inquiry and Notification System}

The terms disaster, crisis, catastrophe, and emergency are used almost synonymously by scholars. A disaster is defined by the United Nations as a serious disruption of the functioning of a society, and catastrophe refers to disasters that cause widespread human, material, or environment losses [23]. Therefore, disaster management problems are inherently complex, time-bound, and multi-faceted. Such problems involve many decision-makers, high stakes, limited technical information, and difficult tradeoffs [2,25], in which information systems that use information and communication technologies are becoming increasingly important as ways to coordinate and support emergency management. Four phases can be identified in the emergency management process: preparedness, mitigation, response, and recovery. Emergency management information systems (EMIS) play a critical role in the disaster response phase, because the EMIS can collect and coordinate distributed information and support the personnel involved so that immediate actions can be taken during and after the disaster [26]. Numerous EMISs already exist. Current literature on EMIS can be placed into three categories: system frameworks, design requirements and approaches, and critical factors and applications, based on different perspectives (e.g., emergency response, e-government, IT service management, and decision support systems) [27].

Disaster inquiry and notification systems are parts of EMIS; such systems provide information for disaster managers, local authorities, and emergency services. This information is subsequently disseminated to the public to provide sufficient time for effective mitigative actions before the disaster arrives [28]. Disaster inquiry and notification systems are critical when flooding is imminent. The flood inquiry and notification systems can be placed into two categories: sensor-based and human eye-witness-based. A sensor-based flood monitoring and detection system uses a rainfall recorder and a water level recorder to collect the data to predict water level. Nowadays, most flood detection systems utilize a wireless sensor network (WSN) [29], which consists of numerous sensors with the capabilities to monitor environmental conditions through wireless communications and computations. The disaster inquiry and notification system then passes the detected and recorded data through the internet to an emergency center for further analysis and decision making [30].

\subsection{Volunteer Information and Disaster Inquiry and Notification System}

Flood inquiry and notification by human eye-witnesses has been in use for many years. Such human-based notifications have their own benefits and risks. In most developed countries, 
flood inquiry and notification management rely largely on a workforce of professionals and trained volunteers who are affiliated with official agencies due to their high specialization [31]. These professionals and trained volunteers can provide the precise information required for flood emergency decision-making. However, given the increasing frequency of flood disasters worldwide due to population growth, urban development, and climate change, professionals and trained volunteers are not sufficient for monitoring flood disasters and damages in the field during a disaster, and they often remain long after official services have ended [32]. Ordinary citizens provide much of the additional surge capacity required to respond to more frequent emergencies and disasters in the future [32]. Various scholars have argued about the value of ordinary citizens and their participation in disaster notification systems. For example, Shan et al. [27] argued that disaster notification systems should involve both government departments and the public in collecting emergency information, responding to feedback, connecting to external information, and providing emergency rescue proposals. Palen et al. [33] believed that better emergency management should include activities and information from the public; such activities and information rely on the integration of multiple subfields of computer science and a commitment to understanding the domain applications. Jaeger et al. [34] explored the viability of facilitating resident-to-resident assistance to coordinate community responses to disasters.

Recent studies have shown that implementations of flood inquiry and notification by ordinary citizens including the household and individual citizen levels are adequate [35-37]. However, empirical literature on inquiries and notification by corporate volunteers is still scarce, specifically about how corporate volunteers' capabilities can be integrated into public flood-management systems. Further studies on corporate volunteers can be very useful.

\subsection{Public-Private Partnership (PPP)}

The public-private partnership (PPP) concept is often used as "the collaboration between a public sector (government) entity and a private sector (for-profit) entity to achieve a specific goal or set of objectives" [38]. According to the categorization of PPPs being adopted by the European Union [39] and many other countries, there are two types of PPPs: the contractual PPPs and the institutionalized PPPs, according to the legal status and governance model. Contractual PPP refers to the relationship between public and private sectors based on the formal contact, which is typically structured with a special juridical and economic purpose. In the contractual PPPs, the private partners are solely responsible for providing services based on a rigid written contract. Instead, the institutionalized PPPs join the public and private partners together in a single PPP to manage and deliver the services. Institutionalized PPPs mix public and private firms included in joint-ventures between public sector entities and private investors [40,41]. The low-cost airport of Charleroi in Belgium is an example of institutionalized PPP. The shareholders' structure of Charleroi airport has diversity investors: the Regional Authorities $(28 \%)$, Sowaer $(49 \%)$, venture capital firm-Sambrinvest (19\%), private construction company-Sabca $(1 \%)$, and Sonaca (aerospace industry) $1 \%$. However, the influence of the public authority in airport management is larger than the one provided by its shares, because the Regional Authority also owns $100 \%$ of Sowaer and $50 \%$ of Sambrinvest [42].

The primary characteristics of PPPs are that added value can be achieved from greater co-operation between public and private actors [43]. None of the definitions have specified that remuneration to the private sector of PPP will necessarily be through user charges [44]. Thus, the governments worldwide agree that PPP should be considered in further disaster management. Increasingly, countries are adopting policies that emphasize the importance of PPPs in disaster resilience. These PPP-related policies recognize that preventing breakdowns of critical infrastructures during disasters cannot be assured even with investment levels exceeding the capacity of most economies; hence, they focus on risk reduction via co-operation between public and private actors rather than risk prevention [45].

Numerous PPP studies have been conducted since the late 1990s, focusing mostly on the success factors of PPP [46]. For example, Osei-Kyei et al. [46] reviewed the studies of the critical success factors for PPP and then identified that risk allocation and sharing, strong private consortium, 
political support, community/public support, and transparent procurement are critical success factors. Other research areas, such as project management [47], disaster management [48], and corporate social responsibility [49], have also been explored and investigated. The PPP has become a topic of increasing interest to national governments, universities, and scholars around the world. However, most studies have focused on general or institutionalized PPPs. The contractual PPPs were less studied, and still need more attention. The factors that can enable future implementation(s) of contractual PPP projects, and thus, reduce costs, as well as add value, to public interests, should be explored. Therefore, this paper aims to explore further contractual PPPs, downplay conflicts of interest, and achieve win-win outcomes in partnerships in the disaster management area.

\subsection{Information System Success Model}

Information systems are used to communicate, coordinate, and support disaster inquiry, as well as notify and mitigate emergency events. Many competing theoretical models, such as classic Technology Acceptance Model, Decomposed Theory of Planned Behavior (DTPB), and diffusion of innovations (IDT), coexist in the information system acceptance and adoption literature, each with a different focus and each tested in different contexts. In the field of information system evaluations, DeLone and McLean [50] conducted a landmark study. After reviewing more than 180 papers researching the factors affecting information technology investment, DeLone and McLean developed the information system success model, which is comprised six factors, system quality, information quality, user satisfaction, system use, individual impact, and organizational impact. In 2003, as the service concept was added to information technology along with the use of the Internet, DeLone and McLean [51] further improved the model by adding "service quality" as one of the information system success factors and analyzed the interdependence and correlation of these seven factors (refer to Figure 1). Their proposed information system success model has been widely accepted for the evaluation of information systems in various applications.

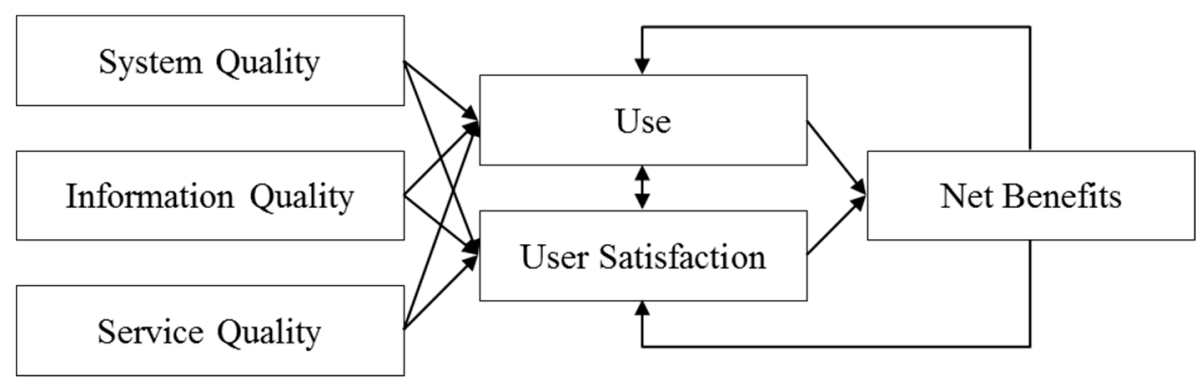

Figure 1. DeLone and McLean information system success model [51].

Many researchers have constructed research frameworks based on the information system success model. For example, Chen [52] evaluated success factors for emergency management engineering information system (EMEIS) based on the information system success model and found that five critical success factors are significantly related: internal organization management, quality of product and technology of suppliers, external technical environment, external policy environment, and coordination and supportive ability of the information center. Lee et al. [53] examined the information systems success model in disaster management of public safety, finding that information quality and system quality are major barriers to efficient and effective multi-agency decision-making, and are critical antecedents to information systems success for efficient and effective disaster management.

\subsection{The Analytic Framework}

The framework of this study-the success factors of corporate volunteer participation in public flood disaster inquiry and notification systems-is based on the information system success model developed by DeLone and McLean. The assessment system uses five dimensions of DeLone and 
McLean's model: system quality, information quality, service quality, user satisfaction, and benefits. In DeLone and McLean's [50] original model, information system success was measured at both individual and organizational levels and is determined by systems use and user satisfaction. Because the stakeholders of flood disaster inquiry and notification systems are from multiple agencies-corporate volunteers, public flood disaster management sectors, and information system service providers-information system success is not used to support multi-agency DM operations [53]. We changed user satisfaction to system satisfaction to include all stakeholders. Additionally, we added PPP as one of the influencing dimensions through the Modified Delphi method. The description of five dimensions of DeLone and McLean's model in corporate volunteers into the flood disaster inquiry and notification system application as Table 1.

Table 1. Five dimensions of DeLone and McLean's model in corporate volunteers into the flood disaster inquiry and notification system application.

\begin{tabular}{|c|c|}
\hline Dimensions & Description \\
\hline $\begin{array}{l}\text { System } \\
\text { Quality }\end{array}$ & $\begin{array}{l}\text { System quality is defined as the degree to which system users believe that } \\
\text { a system is easy to use, user-friendly, easy to learn, easy to connect to, } \\
\text { and enjoyable to use [54,55]. The quality of an information system concerns the } \\
\text { whole process, from the methodology used for IS development to the process of } \\
\text { transferring a completed system [56]. System quality concerns the performance } \\
\text { characteristics of the information systems measured in terms of ease of use, being } \\
\text { easy to learn, response time, and flexibility [53]. Therefore, system quality can be } \\
\text { a measure of the functionality of the information system itself, including } \\
\text { performance characteristics, such as contents of the database, data accuracy and } \\
\text { reliability, response time, and ease of use [57], and thus technical success [50]. } \\
\text { The measurement of quality of information system can help ascertain the "fitness } \\
\text { for use" of the information system and identify benefits in terms of usage and } \\
\text { improvements in productivity [58]. } \\
\text { In the context of flood disaster inquiry and notification, system quality is used to } \\
\text { evaluate the response time being generated by the output. From the aspect of } \\
\text { corporate volunteers, being easy to learn, and ease of use are the two most } \\
\text { dominant measures. From the organizational aspect, the system response time } \\
\text { and fast integration into public flood-management system during disaster are } \\
\text { more important measures, since the corporate volunteers are one of the flood } \\
\text { disaster inquiry and notification sources, and the available time for flood disaster } \\
\text { inquiry and notification is very limited in floods. }\end{array}$ \\
\hline $\begin{array}{l}\text { Information } \\
\text { Quality }\end{array}$ & $\begin{array}{l}\text { Information quality is the desirable characteristics of the system outputs, i.e., } \\
\text { management reports and Web pages [59], and it can be defined as the degree to } \\
\text { which system users think that online learning information is up-to-date, accurate, } \\
\text { relevant, comprehensive, and organized [55,60]. According to the definition by } \\
\text { Eppler [61], information quality is composed of the characteristics of an } \\
\text { information product (e.g., a set of information bundled for a specific purpose) } \\
\text { that is of high value to its users and meets or exceeds the requirements of all its } \\
\text { stakeholders [62]. Information quality measures the quality of the output } \\
\text { produced by the information system, including such items as output timeliness, } \\
\text { reliability, completeness, and appearance [57], which are the values being } \\
\text { perceived by a customer of the output produced by information [63,64]. The } \\
\text { mitigation operations of disasters (including floods) are information-intensive } \\
\text { processes [53]. The effectiveness of such operations depends largely on the } \\
\text { availability of necessary information. The attributes of information quality } \\
\text { included in this study include accuracy, completeness, usefulness, and timeliness. }\end{array}$ \\
\hline
\end{tabular}


Table 1. Cont.

\begin{tabular}{|c|c|}
\hline $\begin{array}{l}\text { Service } \\
\text { Quality }\end{array}$ & $\begin{array}{l}\text { Service quality is the quality of the support that system users receive from the } \\
\text { information systems organization and IT support personnel [59]. According to } \\
\text { Delone and Mclean [51], service quality of an information system is concerned with } \\
\text { information technology organizations, and measuring and comparing user } \\
\text { expectations and their perceptions of the effectiveness of the information technology } \\
\text { organization [51]. Service quality signifies overall customer evaluations and } \\
\text { judgements about the quality of service delivery by an information system [64]. } \\
\text { Service quality can be evaluated using attributes, which include tangible, reliability, } \\
\text { responsiveness, assurance, functionality, interactivity, and empathy [51,55,65,66]. } \\
\text { In the context of flood disaster inquiry and notification, the attributes include } \\
\text { individual services, empathy, incentives, procedure consistency, and information } \\
\text { feedback. The flood disaster inquiry and notification require skills in geographic } \\
\text { information systems (GIS) and reports. Corporate volunteers may not receive } \\
\text { training in advance. They may want to do something to help but may not know how } \\
\text { or who to contact. System service may offer individual services, specific training, } \\
\text { or incentives to engage volunteers. In addition, Rogstadius, Jakob, et al. [67] } \\
\text { highlighted that new tools may be a mismatch between system functionality and } \\
\text { decision-makers' needs because of the suitable procedures for volunteer } \\
\text { management. Thus, the attributes of service quality include procedure consistently } \\
\text { and information feedback. }\end{array}$ \\
\hline $\begin{array}{l}\text { System } \\
\text { Satisfaction }\end{array}$ & $\begin{array}{l}\text { User satisfaction is the recipient's response to the use of the outcomes of an } \\
\text { information system [51]. Lin and Wang [68] defined user satisfaction as system user's } \\
\text { satisfaction with system speed, number of functions, quality, and format. User } \\
\text { satisfaction is considered one of the main indicators when assessing the success of } \\
\text { new system adoption, and it has been widely used as a measure in the field of IS [59]. } \\
\text { According to Hu [69], user satisfaction refers to the extent to which a user perceives } \\
\text { a system to be useful and wants to use it again. Attitudes toward the flood disaster } \\
\text { inquiry and notification system have been measured by achievement, } \\
\text { constant improvement, and volunteer number growth rate. }\end{array}$ \\
\hline Benefits & $\begin{array}{l}\text { Benefit is the extent to which information systems contribute to the success of } \\
\text { individuals, groups, organizations, industries, and nations [70]. Benefits have been } \\
\text { suggested to range from efficiency gains to public disaster management sector and } \\
\text { corporate volunteers [71]. } \\
\text { The attitudes of the flood disaster inquiry and notification system include cost } \\
\text { reduction, quality of decision, economic benefits to corporate volunteers, } \\
\text { non-economic benefits to corporate volunteers, and the corporate-government } \\
\text { trust relationship. }\end{array}$ \\
\hline $\begin{array}{l}\text { Public-Private } \\
\text { Partnership }\end{array}$ & $\begin{array}{l}\text { A Public Private Partnership is generally a medium- to long-term relationship } \\
\text { between the public and private sectors (including the voluntary and community } \\
\text { sector) involving the sharing of risks and rewards and the utilization of } \\
\text { multi-sectoral skills, expertise, and finance to deliver desired policy outcomes that } \\
\text { are in the public interest [72]. A public-private partnership is a contractual agreement } \\
\text { formed between public and private sector partners that allows more private sector } \\
\text { participation rather than traditional participation [73]. The public private partnership } \\
\text { is a (relatively) long-term collaboration as a part of an objective to provide a public } \\
\text { service as defined by public authority [74]. The measures for evaluating the } \\
\text { public-private partnership between a corporate volunteer and the flood disaster } \\
\text { inquiry and notification system include regulations, social responsibilities, contract } \\
\text { relationship, and partner relationship. }\end{array}$ \\
\hline
\end{tabular}

\section{Methodology}

Flood disaster management problems are inherently complex and multi-faceted, involving many decision-makers, high decision-stakes, limited technical information, and difficult tradeoffs [2]. The MCDM method can model multi-faceted complex systems because of its simplicity and generality. Thus, we employed both qualitative and quantitative methods in the study. We used the qualitative approach of focus group discussion to establish a research framework comprising a set of determinants in the context of formation system success model. Then, the Modified Delphi method was introduced 
to confirm the dimensions and factors. A hybrid MCDM framework consisting of DEMATEL and ANP was developed for flood disaster inquiry and notification system evaluation in this study. DEMATEL [20] was used to construct an IRM and derive the interrelations between factors. Based on the IRM, the ANP being proposed by Saaty [75] was used to derive the weights. The analytic framework allows us to establish a decision-making framework for a flood disaster inquiry and notification system evaluation (refer to Figure 2).

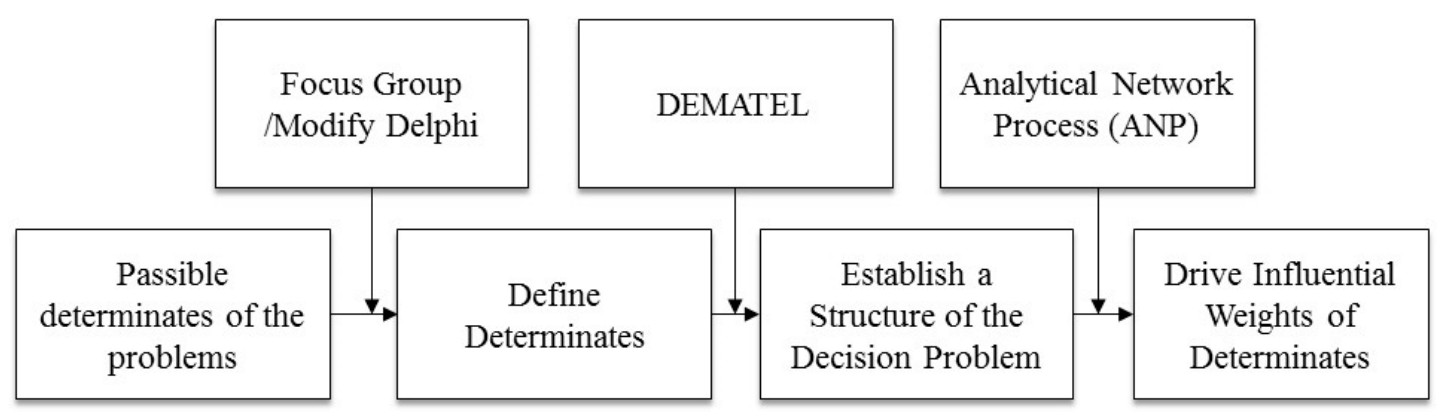

Figure 2. Research Flow of decision-making framework.

Various MCDM approaches such as the ANP, ELECTRE, the Weighted Sum Model (WSM), the Technique for Order of Preference by Similarity to Ideal Solution (TOPSIS), and the Preference Ranking Organization Method for Enrichment Evaluation (PROMETHEE), etc., can be considered while selecting appropriate methods for solving a decision making problem. However, assumptions, weakness or limitations associated with some methods limit the applications of such methods in this work. For example, the weighted sum model (WSM) is the simplest and the most commonly used aggregation operator in MCDM [76]. The TOPSIS method determines a solution with the shortest distance to the ideal solution and the greatest distance from the negative-ideal solution, but it does not consider the relative importance of these distances [77]. The ELECTRE and the PROMETHEE were proposed for ranking alternatives. However, the ELECTRE is weak regarding provisions of ranking scores and intransitivity [78]. The definitions of proper preference functions being required by PROMETHEE are not easy. The Analytic Hierarchical Process (AHP) is one of the traditional methods for deriving weights being associated with each aspect and criteria. A common problem for the above-mentioned MCDM methods is the assumption of independence among criteria, which is unrealistic for decision problems in the real world. Since aspects and criteria inside real-world decision making problems always influence other, an analytic framework consisting of the DEMATEL and the ANP is very suitable. The influence of relationships between the aspects and criteria can be constructed by using the Decision Making and Trial and Evaluation Laboratory (DEMATEL). The ANP can be used to derive the weights associated with each aspect and criterion when considering the influence relationships, and thus the dependences between these aspects and criterion. Therefore, a combination of the DEMATEL and the ANP is very reasonable and suitable for the derivation of factors influencing the successful integration of corporate volunteers into public flood disaster inquiry and notification systems, since dependences between aspects and criteria exist in such problem(s) and should be considered.

\subsection{Modified Delphi Method}

The Delphi method, designed by Dalkey and Helmer [79], is a method for structuring a group communication process to facilitate group problem-solving and to structure models. The method can be applied to problems that do not lend themselves to precise analytical techniques but rather to those that could benefit from the subjective judgments of individuals on a collective basis and that focus their collective human intelligence on the problem at hand [80]. In other words, when the knowledge of a problem or phenomenon is insufficient, the Delphi method can be used as a quantitative technique. 
The Delphi method is a mature and very adaptable research method used in many information systems and IT research arenas [81].

Murry and Hammons [82] modified the traditional Delphi technique by replacing the first round of a survey with the conventionally adopted open style survey. The modified Delphi technique is similar to the full Delphi in terms of procedure and intent. The advantages of the modified Delphi method include time savings and a focus on research themes, eliminating the need for speculation on the open questionnaire and improving the response to the main topic [83]. Accordingly, in this investigation, we developed a quality evaluation criterion to evaluate the factors enabling corporate volunteers to monitor flood disasters by combining the modified Delphi method with interviews of anonymous experts.

\subsection{DEMATEL Method}

The Geneva Research Centre of the Battelle Memorial Institute developed the DEMATEL method to convert complex systems into a clear causal structure that simplifies interrelationships among consideration factors [20]. The aim of the DEMATEL method is to identify direct and indirect causes and the strength of influence of considered factors by applying matrix computations. Unlike the classical approach of structural equation modeling (SEM), which requires a large sample size to derive causal relationships among variables, the expert opinion-driven DEMATEL method can yield good results from a relatively small sample size [84] and assess the associated cause and effect relationships [85].

The DEMATEL technique has been frequently applied in many situations, such as identifying the key successful factors in emergency management [86], flood mitigation [87], and risk factors of IT outsourcing [88]. Because the current study concentrates on the adoption of corporate volunteers into the public flood information system, survey respondents need to possess both a good understanding of flood emergency management and a background in information systems. The available sample size of those with such qualifications was understandably limited. As such, we employed the DEMATEL method to identify the causation and the strengths of influence of the considered factors. The method can be summarized based on the earlier works by Tzeng and Huang [89], as well as Yang et al. [90]. Please refer to Appendix A for the detail procedures.

\subsection{ANP Method}

AHP and ANP are two popular MCDM methods that aid decision-makers to derive weights for evaluating and select the best choice in situations characterized by more than one criterion. AHP, introduced by Saaty [75], is a useful approach for resolving complex decision-making problems with some impact factors through the process of analyzing, estimating, and synthesizing. ANP extended the AHP to address restrictions of the hierarchical structure in which criteria are independent from each other. ANP can systematically overcome all types of dependencies by allowing interaction and feedback both within criteria (inner dependence) and between clusters (outer dependence). In fact, ANP uses a network without needing to designate levels, as in a hierarchy. A network of ANP can build a control hierarchy or network of criteria and sub-criteria that controls the interactions and then identifies influences and weights among the components and their clusters [90]. The method can be summarized based on the earlier works by Saaty [75] and Yang et al. [91]. Please refer to Appendix B for the detail procedures.

\section{Empirical Study}

In this section, an empirical study is discussed to illustrate the application of the proposed model for evaluating flood disaster inquiry and notification systems in Taiwan. First, the background and nature of the empirical study case in Taiwan are introduced. Then, we describe a group discussion meeting we held for the study. We used modified Delphi methods to construct the decision-making framework by inviting domain experts from the water resource agency in Taiwan. 
Subsequently, we designed questionnaires in compliance with DEMATEL and ANP format to derive the relationships among factors.

\subsection{Flood Disaster Inquiry and Notification System in Taiwan}

Taiwan is an island highly vulnerable to natural disasters. The five major natural hazards confronting Taiwan include typhoons, earthquakes, landslides, floods, and debris flow [92,93]. In Taiwan, $73 \%$ of the land and population are exposed to three or more types of natural hazards, and $90 \%$ of the land and population are exposed to two types of hazards. Since Taiwan is located on the western edge of the Pacific Ocean and in a typhoon-prone area, typhoons bring heavy rainfall in July and August of each year. With an average of 3.6 typhoons per year, flood hazards have significantly affected the lives of Taiwan residents and have caused severe property loss. For example, in 2009, one of the deadliest typhoons, Morakot, dumped heavy rain on Taiwan and caused one of the most severe natural disasters. Typhoon Morakot destroyed 61,163 houses completely or partially, which accounted for $\$ 5$ billion losses [94] and resulted in 643 fatalities. After Typhoon Morakot, the Taiwanese Water Resources Agency (WRA) of Ministry of Economic Affairs in Taiwan reconfigured the national disaster notification system. In the past, the Water Resource Agency monitored flood disasters by passively receiving information from the public and the media. However, since 2010, the WRA changed the attitude and started to monitor the disaster information proactively. The WRA recruited and trained volunteers every year to monitor the current conditions of flood disaster because of limited labor to perform extensive flood inspections. To become a qualified monitor, volunteers must attend training sessions held by the WRA. In 2011, the WRA reconfigured flood volunteers by engaging corporate volunteers in the original public flood notification systems. To get effective and timely flood information form volunteers, WRA operates a platform flood disaster inquiry and notification system built by Chunghwa telecom in Taiwan. The flood disaster inquiry and notification system is a part of "Disaster Prevention Information Service Network" (Website: http://579.wra.gov.tw/dn/). The public flood control volunteers and corporate volunteers may report the current flood status using the flood disaster inquiry and notification system.

Corporate volunteers who are involved in flood monitoring include clerks of the largest 24-h convenient store system, the 7-Eleven Corporation, the Taiwan Sugar Corporation (Taisugar), and the employees of the leading all-day operated gas station chains, the Chinese Petroleum Corporation (CPC). Since the corporate volunteers are from the largest 24-h shop chains, the notification system can operate $24 \mathrm{~h}$ a day, 365 days per year, and in most urban areas of Taiwan. Included in this system are 7027 notification sites. At least one site can be found in each town and village. To monitor the flood disasters, the system automatically informs the clerks of the 7-Elevens and the employees of the gas stations using auto dial and automatic speech recognition systems about whether a flood is happening and whether the flood level is more than $30 \mathrm{~cm}$ or less. The clerks or the employees can reply easily by pressing buttons to send a message to the Water Resource Agency in about three minutes. Comprehensive information on the flood can be completely collected by the system in $30 \mathrm{~min}$. Such corporate volunteers can serve as a reference for resource allocation and rescue-team dispatches. The system also provides flood disaster notification information to the 7-Eleven post and display system.

\subsection{Decision-Making Framework Construction}

To identify the factors influencing the integration of corporate volunteers into public flood disaster inquiry and notification systems, this study used the information systems success model and the PPP model to define the decision-making framework based on experts' opinions summarized by Delphi. Five domain experts were heavily involved in the focus group meetings. They were asked to identify possible factors enabling corporate volunteers to provide information to the flood disaster inquiry and notification system. The rigor and validity of the results were further confirmed by the modified Delphi method by summarizing opinions provided by 18 experts. The experts included water resource agency 
officers, information system service providers, managers from the 7-Eleven Corporation, and flood disaster notification researchers. All experts had more than five years of work experience related to flood disasters. As a result, 24 factors belonging to 6 dimensions were summarized. After confirming the possible criteria using the Modified Delphi method, an evaluation framework for investigating the factors influencing the integration of corporate volunteers into the flood disaster inquiry and notification system evaluation model was constructed (Table 2).

\subsection{Results}

To assess the effects among the various criteria and then derive the weights being associated with the criteria, the causal structures were developed first by using the DEMATEL method. Then, the weights being associated with each criterion were derived using the ANP methods. Experts' opinions regarding the influence of one factor on another were assessed using the DEMATEL method; subsequently, using Equations (A1)-(A3), we derived the total influence among the six dimensions defined in Table 2. The total relation matrices of factors belonging to each dimension were also derived and demonstrated in Equations (A9)-(A15). Using Equations (A4) and (A5), the causal diagram was constructed based on the $r_{i}$ and $c_{i}$ values (refer to Table A1) derived from the total relationships among the dimensions and among the factors within their respective dimensions. The causal diagrams are demonstrated in Figure 3. In this research, the threshold value was set as the average value $(\mu)$ plus $1 / 2$ times the standard deviation $(\sigma)$ of all the items in the total relationship matrix T. Accordingly, the structure of the decision problem can be defined based on the influence of the relationships or the IRM derived using DEMATEL. The IRM can serve as the basis for the ANP, which can be used to derive relative importance of each factor based on the opinions provided by the 16 experts. Based on the pairwise comparison of the factors obtained from the ANP questionnaire, the unweighted supermatrix $\boldsymbol{W}_{c}$ and limited supermatrix were calculated using Equations (A6)-(A8) according to the Super Decisions. The results are demonstrated in Equations (A16) and (A17). The weights corresponding to each dimension and criteria were thus obtained based on the weighted supermatrix. The results are summarized in Table 3.

The results of DEMATEL methods are illustrated in Figure 3. The axes represent the degree of influence of one dimension on another dimension, or those of one criterion on another criterion, in which the criteria belong to the same dimension. Apparently, system quality(A) dominates and influences all the other dimensions. The research results indicated that system quality (A), information quality (B), and service quality (C) influence corporate volunteers, encouraging them to engage more aggressively in disaster response during flooding. User dimensions, such as system satisfaction (D), benefit (E), and public-private partnership (PPP) (F), are dimensions that are mainly influenced by other dimensions.

According to Table 3, the importance of dimensions can be prioritized as (1) System Quality (A), (2) System Satisfaction (D), (3) Benefits (E), (4) Information Quality (B), (5) Public-Private Partnership (F), and (6) Service Quality (C). Furthermore, the local weights are transformed into global weights, which allow us to compare the importance of factors across six dimensions. The top-ranking factors with the highest weights included (1) being easy to use $\left(a_{1}\right),(2)$ results being achieved $\left(d_{3}\right)$, (3) partner relationship $\left(f_{3}\right)$, and (4) regulations/social responsibilities $\left(f_{1}\right)$. Those criteria are the most important ones for integrating corporate volunteers into the public flood disaster inquiry and notification system. 
Table 2. Possible dimensions and criteria for deriving the factors influencing the integration of corporate volunteers into the flood disaster inquiry and notification system.

\begin{tabular}{|c|c|c|}
\hline Dimensions & Factors & Descriptions \\
\hline \multirow{4}{*}{$\begin{array}{l}\text { System } \\
\text { Quality (A) }\end{array}$} & Easy to use $\left(a_{1}\right)$ & Information system is easy to use \\
\hline & Easy to learn $\left(a_{2}\right)$ & Information system is easy to learn. \\
\hline & Response time $\left(a_{3}\right)$ & $\begin{array}{l}\text { Information system communicates information } \\
\text { quickly to the emergency responders. }\end{array}$ \\
\hline & Interoperability $\left(a_{4}\right)$ & $\begin{array}{l}\text { Information system integrates various corporate } \\
\text { and public inquiry and response operations. }\end{array}$ \\
\hline \multirow{4}{*}{$\begin{array}{l}\text { Information } \\
\text { Quality (B) }\end{array}$} & Accuracy $\left(b_{1}\right)$ & The flood information is accurate. \\
\hline & Completeness $\left(b_{2}\right)$ & The coverage rate of the area is high. \\
\hline & Usefulness $\left(b_{3}\right)$ & $\begin{array}{l}\text { The information is useful from the dimension of } \\
\text { emergency support and recovery. }\end{array}$ \\
\hline & Timely updating of information $\left(b_{4}\right)$ & $\begin{array}{l}\text { The system can update information in } \\
\text { a timely manner. }\end{array}$ \\
\hline \multirow{5}{*}{$\begin{array}{l}\text { Service } \\
\text { Quality (C) }\end{array}$} & Individual services $\left(c_{1}\right)$ & $\begin{array}{l}\text { The system provides services to individual users } \\
\text { (e.g., actual personnel repartee). }\end{array}$ \\
\hline & Empathy $\left(c_{2}\right)$ & $\begin{array}{l}\text { The system offers users specific training needs } \\
\text { (e.g., online tutorials on YouTube, } \\
\text { face-to-face training). }\end{array}$ \\
\hline & Incentives $\left(c_{3}\right)$ & $\begin{array}{l}\text { The system provides incentives to corporate } \\
\text { volunteers so that the firms are willing } \\
\text { to cooperate. }\end{array}$ \\
\hline & Procedure consistently $\left(c_{4}\right)$ & $\begin{array}{l}\text { The system is consistently courteous with users } \\
\text { business processing and decreases interference. }\end{array}$ \\
\hline & Information feedback $\left(c_{5}\right)$ & $\begin{array}{l}\text { The system provides users' statistics of disaster } \\
\text { response rates to companies for improvement. }\end{array}$ \\
\hline \multirow{3}{*}{$\begin{array}{l}\text { System } \\
\text { Satisfaction } \\
\text { (D) }\end{array}$} & Results being achieved $\left(d_{1}\right)$ & $\begin{array}{l}\text { The system achieves expected results of original } \\
\text { floods investigations. }\end{array}$ \\
\hline & Constantly improves $\left(d_{2}\right)$ & The system can be improved constantly. \\
\hline & Volunteer number growth rate $\left(d_{3}\right)$ & $\begin{array}{l}\text { More firms can be recruited to increase the total } \\
\text { number of corporate volunteers. }\end{array}$ \\
\hline \multirow{5}{*}{ Benefits (E) } & Cost reduction $\left(e_{1}\right)$ & $\begin{array}{l}\text { The cost of flood data collection can significantly } \\
\text { be reduced. }\end{array}$ \\
\hline & Quality of Decision $\left(e_{2}\right)$ & $\begin{array}{l}\text { The quality of decision can be } \\
\text { significantly enhanced. }\end{array}$ \\
\hline & $\begin{array}{l}\text { Economic benefits to Corporate } \\
\text { Volunteers }\left(e_{3}\right)\end{array}$ & $\begin{array}{l}\text { The system can bring benefits to the corporate } \\
\text { volunteers (e.g., mitigate flood damages and } \\
\text { enhance customers' purchase intensions). }\end{array}$ \\
\hline & $\begin{array}{l}\text { Non-economic benefits to Corporate } \\
\text { Volunteers }\left(e_{4}\right)\end{array}$ & $\begin{array}{l}\text { The system has potential benefits for corporations } \\
\text { (e.g., public interests and the coherence of staff). }\end{array}$ \\
\hline & $\begin{array}{l}\text { Corporate-government trust } \\
\text { relationship }\left(e_{5}\right)\end{array}$ & $\begin{array}{l}\text { The collaboration may enhance trust between the } \\
\text { government and corporations. }\end{array}$ \\
\hline \multirow{3}{*}{$\begin{array}{l}\text { Public-Private } \\
\text { Partnership } \\
\text { (F) }\end{array}$} & Regulations/social responsibilities $\left(f_{1}\right)$ & $\begin{array}{l}\text { Regulations and social responsibility can } \\
\text { encourage corporates to serve as volunteers. }\end{array}$ \\
\hline & Contract relationship $\left(f_{2}\right)$ & $\begin{array}{l}\text { The government should contract with the } \\
\text { corporations (e.g., defining obligations } \\
\text { and responsibilities). }\end{array}$ \\
\hline & Partner relationship $\left(f_{3}\right)$ & $\begin{array}{l}\text { The government establishes partnerships with } \\
\text { firms to become corporate volunteers } \\
\text { (non-contracted relationship). }\end{array}$ \\
\hline
\end{tabular}



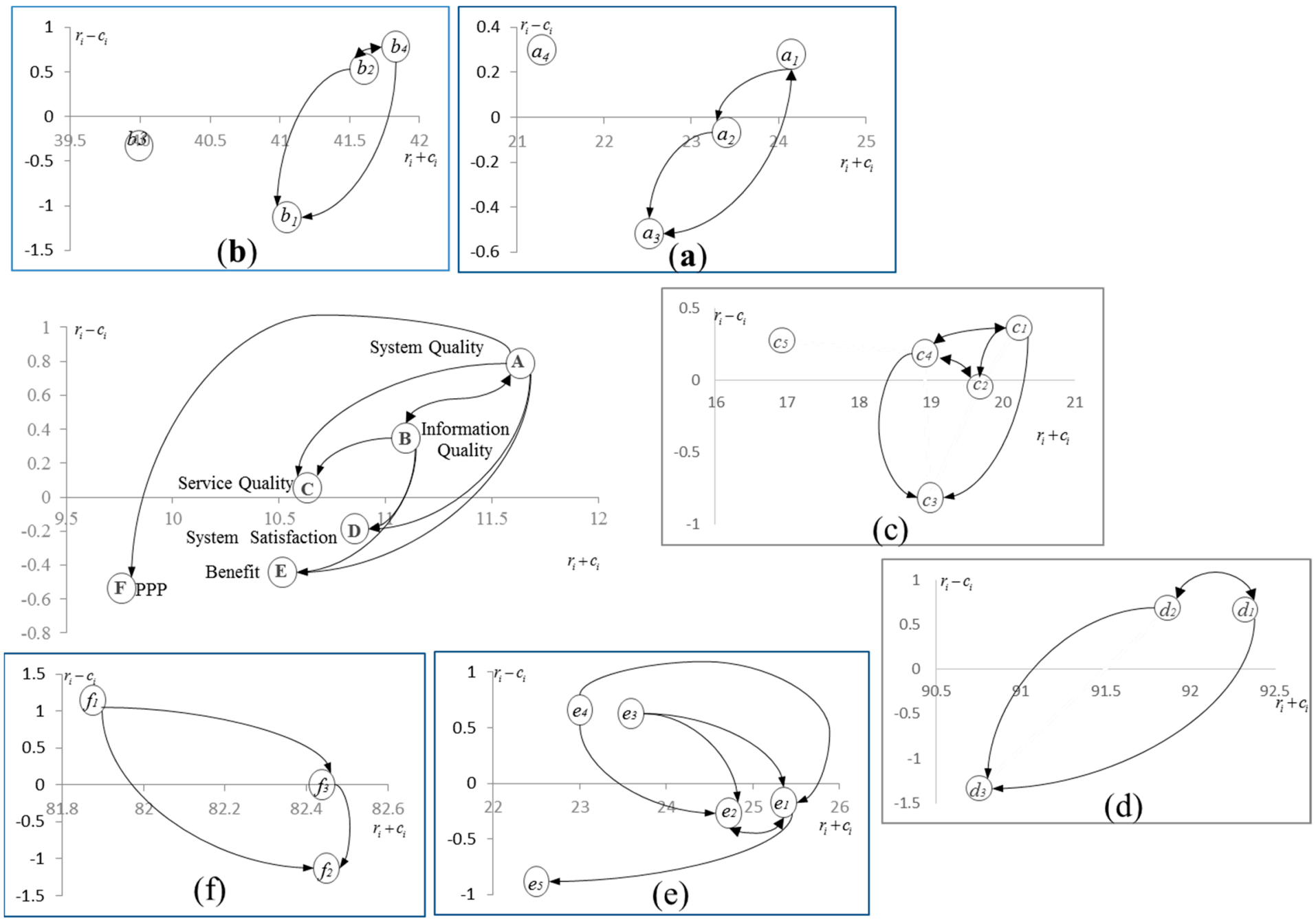

Figure 3. Causal diagram of total relationship. Note: The threshold is set at $\mu+(1 / 2) \sigma$ of the total relationships. 
Table 3. Weights for evaluating Flood Disaster Inquiry and Notification System.

\begin{tabular}{|c|c|c|c|c|c|}
\hline Dimension & Weight & Factors & Local Weight & Global Weight & Rank \\
\hline \multirow{4}{*}{$\begin{array}{l}\text { System } \\
\text { Quality (A) }\end{array}$} & \multirow{4}{*}{$\begin{array}{l}0.171 \\
(1)\end{array}$} & Easy to use $\left(a_{1}\right)$ & 0.385 & 0.066 & 1 \\
\hline & & Easy to learn $\left(a_{2}\right)$ & 0.294 & 0.050 & 8 \\
\hline & & Response time $\left(a_{3}\right)$ & 0.295 & 0.051 & 2 \\
\hline & & Interoperability $\left(a_{4}\right)$ & 0.026 & 0.004 & 24 \\
\hline \multirow{4}{*}{$\begin{array}{l}\text { Information } \\
\text { Quality (B) }\end{array}$} & \multirow{4}{*}{$\begin{array}{l}0.167 \\
(4)\end{array}$} & Accuracy $\left(b_{1}\right)$ & 0.297 & 0.050 & 10 \\
\hline & & Completeness $\left(b_{2}\right)$ & 0.280 & 0.047 & 12 \\
\hline & & Usefulness $\left(b_{3}\right)$ & 0.136 & 0.023 & 22 \\
\hline & & $\begin{array}{l}\text { Timely updating of } \\
\text { information }\left(b_{4}\right)\end{array}$ & 0.288 & 0.048 & 11 \\
\hline \multirow{5}{*}{$\begin{array}{l}\text { Service } \\
\text { Quality (C) }\end{array}$} & \multirow{5}{*}{$\begin{array}{l}0.157 \\
(6)\end{array}$} & Individual services $\left(c_{1}\right)$ & 0.222 & 0.035 & 17 \\
\hline & & Empathy $\left(c_{2}\right)$ & 0.197 & 0.031 & 20 \\
\hline & & Incentives $\left(c_{3}\right)$ & 0.238 & 0.037 & 15 \\
\hline & & Procedure consistently $\left(c_{4}\right)$ & 0.260 & 0.041 & 13 \\
\hline & & Information feedback $\left(c_{5}\right)$ & 0.083 & 0.013 & 23 \\
\hline \multirow{3}{*}{$\begin{array}{l}\text { System } \\
\text { Satisfaction } \\
\text { (D) }\end{array}$} & \multirow{3}{*}{$\begin{array}{l}0.170 \\
(2)\end{array}$} & Results being achieved $\left(d_{1}\right)$ & 0.366 & 0.062 & 2 \\
\hline & & Constantly improvements $\left(d_{2}\right)$ & 0.295 & 0.050 & 9 \\
\hline & & $\begin{array}{l}\text { Volunteer Number Growth } \\
\text { Rate }\left(d_{3}\right)\end{array}$ & 0.339 & 0.058 & 4 \\
\hline \multirow{5}{*}{$\begin{array}{l}\text { System } \\
\text { Benefit (E) }\end{array}$} & \multirow{5}{*}{$\begin{array}{l}0.168 \\
(3)\end{array}$} & Cost reduction $\left(e_{1}\right)$ & 0.234 & 0.039 & 14 \\
\hline & & Quality of Decision $\left(e_{2}\right)$ & 0.215 & 0.036 & 16 \\
\hline & & $\begin{array}{l}\text { Economic Benefits to } \\
\text { Corporate Volunteers }\left(e_{3}\right)\end{array}$ & 0.189 & 0.032 & 18 \\
\hline & & $\begin{array}{l}\text { Non-economic benefits to } \\
\text { Corporate Volunteers }\left(e_{4}\right)\end{array}$ & 0.176 & 0.030 & 21 \\
\hline & & $\begin{array}{l}\text { Corporate-government trust } \\
\text { relationship }\left(e_{5}\right)\end{array}$ & 0.186 & 0.031 & 19 \\
\hline \multirow{4}{*}{$\begin{array}{l}\text { Public-Private } \\
\text { Partnership } \\
\text { (F) }\end{array}$} & \multirow{3}{*}{$\begin{array}{l}0.167 \\
(5)\end{array}$} & $\begin{array}{l}\text { Regulations/social } \\
\text { responsibilities }\left(f_{1}\right)\end{array}$ & 0.345 & 0.058 & 5 \\
\hline & & Contract relationship $\left(f_{2}\right)$ & 0.303 & 0.051 & 6 \\
\hline & & Partner relationship $\left(f_{3}\right)$ & 0.352 & 0.059 & 3 \\
\hline & 1.000 & & 6.000 & 1.000 & \\
\hline
\end{tabular}

\section{Discussion}

The goal of this study was to assess the determinants of influencing integration of Corporate Volunteers into Public Flood Disaster Inquiry and Notification Systems and their relationships to integrate corporate volunteers into public flood inquiry and notification systems through integrating information success model and the PPP model. To this end, we constructed a two-level research framework: a high level consisting of six dimensions and a detail level consisting of 24 factors. After the DEMATEL analysis and further weight analysis using the ANP method, the research results indicated that the importance and causal effects of the determinants at these two levels differed.

\subsection{Managerial Implications from the Dimensions Level}

This study intended to provide an in-depth understanding of the factors enabling the integration of corporate volunteers into the public flood inquiry and notification system. Thus, the public sector can initiate more effective strategies with very limited budgets to achieve the effectiveness, efficiency, and transparency of decisions. Based on the results of DEMATEL (refer to Figure 3), system quality (A) and information quality (B) are the causal dimensions that influence system satisfaction (D), service quality $(C)$, and benefit $(E)$. The improvements in the system quality $(A)$ and information quality (B) can lead to improvements in other dimensions and criteria as well. This finding is consistent with the information system success model proposed by DeLone and Mclean [50]. According to 
DeLone and Mclean [50], information quality (A) and system quality (B) are the key elements for information system success that can also increase user satisfaction. Bharosa et al. [95] further confirmed that information quality and system quality are the key drivers of effective multi-agency disaster management in technical-social contexts (refer to Figure 3).

The system quality (A) with the highest prominence value plays a central role in the result of the DEMATEL, indicating this dimension's highest degree of influence in the total relations. The system quality (A) dimension is also the most critical dimension of the flood disaster inquiry and notification system based on the analytic results being derived by the ANP. The system quality (A) is regarded as a technical or engineering concept, whereas information quality (B) is a pervasive social concept. The reason of system quality (A) with the highest prominence value is that the flood disaster inquiry and notification system involves multiple stakeholders, including the Water Resources Agency, corporate volunteers, and information service providers. Ensuring high information quality among multiple disaster stakeholders is difficult due to the complexity, dynamics, and uncertainty of disaster management. Emphasizing the efforts into ensuring system quality may reduce the communication barriers among multiple stakeholders. Because the interaction between systems usually occurs within an organizational context, larger problems can always be found in the organizational architecture and can support via technical architecture. Besides, flood disaster information quality depends largely on the effectiveness of information system operations to collect for disaster information. This phenomenon is consistent with previous studies. According to Bharosa et al. [95], the mono-disciplinary system can be joined relatively easily; however, many technical and organizational problems exist among the different parties involved. Although system architects consider the information quality to be a larger concern compared to the system quality, they currently put most of their efforts into ensuring system quality rather than information quality. Further, previous research has also suggested that system quality (A) influences information quality (B). Since information depends largely on system operations and the effectiveness of information collection for disaster management, information quality is most closely related to the output of system quality [96]. Our research results demonstrated the mutual interaction between system quality and information quality.

In addition to the information quality (A) and system quality (B), the results of the DEMATEL revealed that the service quality $(C)$ is also a cause dimension, although it ranked as the least important dimension according to the ANP results. This analytic result is not consistent with the information system success model [51]. According to Delone and McLean [51], service quality directly affects usage intentions and user satisfaction with the system, as well as the net benefits produced by the system. As the information system becomes more complicated and harder to use, users need more service support. However, people in emergencies have very limited time to deal with service issues unrelated to the emergency. Since the public flood disaster response system is designed to facilitate public administrators' decisions and is not for profit, the government decision-makers focus more on flood disaster information. In the empirical study case in Taiwan, there only two questions for corporate volunteer to respond to: whether a flood is happening, and whether the flood level is more than $30 \mathrm{~cm}$ or less. The system is designed to be easy to reply to and is service-free. Thus, service quality was not ranked as dominant according to the ANP result, which is also consistent with prior works.

The PPP (F) dimension ranked lower in priority compared to the system quality (A), information quality (B), and service quality (C) dimensions from the results of ANP. This research finding concurs with the recent study by Auzzir et al. [48]. Auzzir et al. [48] argued that the governments of developing countries are less attractive to actors from private sectors who usually do not actively participate in disaster management. This phenomenon is inconsistent with that observed in developed countries, where disasters are often managed strategically through public and private collaborations. In developing countries, the public sectors are the sole or major accountable institutions for disaster management because public institutes do not have sufficient resources in integrating flood information effectively. Traditionally, accurate flood information should be received on time at the earliest possibility. Inaccurate information should be detected and verified. Otherwise, the transmission 
or information failure will be notified. This problem is especially significant nowadays, since disaster information is provided by private sectors for disaster management, which could contribute to information overload, lack of trustworthiness, lack of reliable access, and decreased privacy protection of users [97]. In general, public sectors prefer to focus on improving the quality of information, as well as the system, so as to get real-time and accurate information. Acquiring information from the PPPs is not the major focus of these sectors.

In terms of the relationship among the dimensions, Figure 3 reveals that that the PPP (F) dimension is the effect dimension influenced by the system quality (A) dimension. This result is consistent with prior studies on PPP in disaster management, arguing that the efforts should be the core concern of corporate officials [38]. The PPP allows for a better sharing of costs and benefits between private and public sectors [98]. When a government regards one private sector as a full partner that can mitigate, prepare for, respond to, and recover from disasters by its own efforts, the private sector is expected to account for some responsibilities before, during, and after emergencies. Thus, the public and private sector actors need to define their roles in the partnership. However, in the empirical case, no contract or agreement between the public sector(s) and corporate volunteer(s) is available. Unless the responsibilities of public volunteers are clearly defined in advance, i.e., the system quality (A) can be assured, nothing can be expected from the partnership (i.e., PPP, or the dimension F). Such phenomenon can eventually erode the effectiveness of the partnership; even worse, the partnership can be abandoned [38]. This result is consistent with earlier works by Steijn et al. [43], who argued that when projects become more complex, the degree of PPP increases. Simple system quality does not need to address PPP but use of less complex arrangements. Our research provides the evidence of the influence of the relationships of system quality (A) and PPP (F).

\subsection{Criteria in the System Quality (A) Dimension}

Among the factors of the system quality (A) dimension, easy to use $\left(a_{1}\right)$ the flood information system is the most important criterion, with a weight of 0.358 . The ease of use $\left(a_{1}\right)$ dimension influences easy to learn $\left(a_{2}\right)$ and response time $\left(a_{3}\right)$. This analytic result is consistent with earlier works by McDougall [16]. Ease of use $\left(a_{1}\right)$ is a critical quality requirement for the system, because volunteers with various backgrounds are untrained and are often unable to observe flood conditions immediately. The difficulty of usage of information system should especially be reduced because there is not much or no time for corporate volunteers to learn how the system can be operated during a disaster [95]. The scenario is fully applicable to the empirical study case here, as corporate volunteers, including clerks of convenient stores (i.e., 7-11 here) or managers of gas stations, can be get very busy during a disaster. To encourage corporate volunteers to respond to flood conditions immediately (i.e., within $2 \mathrm{~min}$ ), only 2 questions designed measured using nominal scales are provided: (1) Is it flooding or not? (2) Is the flood depth over $0.3 \mathrm{~cm}$ ? The flood inquiry and notification system uses a telephone-based automatic audience survey system instead of web or mobile applications, which can hinder the usage of system by convenient store clerks or oil station managers. For decision-makers, traditionally, flood disaster management involves local and federal governments, which include county commissions, zoning boards, mayors, planning departments, and other local government entities [22]. Nowadays, flood control and avoidance is no longer the sole role of federal or local governments. Decision-makers also bear responsibility for collecting overall flood information from corporate volunteers within $30 \mathrm{~min}$ and distribute disaster information to all flood management stakeholders. Thus, according to the relationships of the system quality dimension (A) being demonstrated in the upper right-hand side of Figure 2, easy to use $\left(a_{1}\right)$ and easy to learn $\left(a_{2}\right)$ influence the response time $\left(a_{3}\right)$.

\subsection{Criteria in the Information Quality (B) Dimension}

The analytic result demonstrates that accuracy $\left(b_{1}\right)$ is the most important criterion in the information quality dimension. Information accuracy can greatly be improved by incorporating volunteers' into the public flood disaster inquiry and notification systems. Further, numerous mechanisms have been 
developed to improve the information accuracy. For example, information provided by corporate volunteers can be double-checked through other sources, such as sensors or professionally trained staffs. Therefore, corporate volunteers can become another dominant source of flood information. The value of corporate volunteers is undeniable, due to the immediate provisions of flood information. In this regard, timely updating of information $\left(b_{4}\right)$ influences accuracy $\left(b_{1}\right)$, as shown in Figure 3.

\subsection{Managerial Implications from the Corporate Volunteer Perspective}

In contrast to individual volunteers, there are two advantages to using corporate volunteers in monitoring flood hazards. (1) Corporate volunteers provide continuous and concurrent real-time observations of the flood status over a wide area. The monitoring of flood hazards requires continuous and concurrent real-time observations from several monitoring points or stations distributed in a wide geographic area. Such observations cannot be achieved easily by individual volunteers or nonprofit organizations due to the scale and scope of the required observations. As corporate volunteers persist over time, they can earn trust of the key stakeholders. Such trust enables further cooperation and thus more meaningful contributions [99]. (2) Additionally, corporate volunteers provide specific domain knowledge, skills, and resources for flood monitoring. Specific knowledge and skills are required to monitor flood hazards. Firms that are willing to provide resources to support corporate volunteers are more likely to provide resources, such as time, money, and manpower, which are necessary when training employees. In general, three implications can be drawn accordingly: (1) corporate volunteers are much more efficient from the aspect of information sharing; (2) corporate volunteers are more knowledgeable and trained about flood hazard; and (3) the self-reinforcing mechanism underlying the relation between system quality and information quality further enhances the efficiency of corporate volunteers.

\subsubsection{Corporate Volunteers Are Much More Efficient from the Aspect of Information Sharing}

According to the traditional definition by Grant [100], corporate volunteers offer their time, knowledge, or skills to the company as a part of a community service, outreach, or social responsibility activity without additional compensation or direct personal remuneration. Very few, if any, prior studies have discussed corporate volunteers who provide their time, knowledge, and skills with the aids of IT competencies, which means resources and capabilities obtained from the local firms. In our empirical study case, the corporate volunteers provided their services with the aid of IT competences belonging to the focal firms, making them more efficient compared to the individual volunteers. This phenomenon is consistent with the reviewed literature. The causal relationships derived in the empirical case further demonstrate this rationale.

Becta [101] described an information system as "a system consisting of the network of all communication channels used within an organization". Such communication channels include face-to-face, broadcast media, mobile communication, electronic channel, written messages, and other channels [102]. Some of the firm-level communication channels (e.g., the broadband network) and the disaster recovery mechanism (e.g., Telecommunication Infrastructure, as well as carrier and support introduced by Yang et al. [91]) are not easily available to individual volunteers. Such firm-level communication channels and information systems can enable faster completion of tasks and activities, accelerate data preparation and transmission times, increase reaction speed, and support decision-making processes-enhancing efficiency [103]; thus, they can guarantee successful flood hazard information delivery even in the event of disasters. In general, the flood disaster inquiry and notification system enables volunteers to communicate by using an information system belonging to the focal firms in a timely manner to ensure successful information delivery.

From the aspects of system response time $\left(a_{3}\right)$, timely updating of information $\left(b_{5}\right)$, and timely information feedback $\left(c_{5}\right)$, firms can assure the above-mentioned factors through the appropriate management of information systems. In contrast, individual volunteers can assure such factors using the information-sharing mechanism, which is not as developed as a specific information system or 
management mechanism (refer Figure 3). According to Lin et al. [104], system response time and output information accuracy belong to the criteria for evaluating the efficiency of an information system. Based on the IRM illustrated in Figure 3, the response time $\left(a_{3}\right)$ criteria in system quality aspect (A) influence the timely updating of information $\left(b_{5}\right)$ in information quality aspect (B). Both the response time $\left(a_{3}\right)$ and the timely updating of information $\left(b_{5}\right)$ can influence information feedback $\left(c_{5}\right)$ of service quality aspect $(C)$. The Flood Disaster Inquiry and Notification System can assure efficiency of an information system from the aspects of the system response time from the system quality aspect (A) and the information quality aspect (B). The positive feedback and relationships of influence further enhance efficiency. Therefore, corporate volunteers, using the information system provided by the focal firms, can deliver information more efficiently compared to individual volunteers via information sharing.

\subsubsection{Corporate Volunteers Are More Knowledgeable and Trained about Flood Hazard}

In Section 4.1, the authors mentioned that since 2010, the WRA has been recruiting and training volunteers every year to help monitor the current conditions of flood disaster because of limited manpower to perform extensive inspections of flooding. To become qualified, monitor volunteers must attend training sessions held by the WRA. Therefore, these corporate volunteers are more knowledgeable and trained about flood hazards.

5.4.3. The Self-Reinforcing Mechanism of the Relation between System Quality and Information Quality Further Enhances the Efficiency of Corporate Volunteers

From the relationships of influence demonstrated in Figure 3, only system quality (A) forms a self-reinforcing mechanism with the information quality (B) aspect, in which the total influence values from system quality aspect to the information quality is 1.073 and the influence from information quality to system quality is 1.001 , as shown in Table 3. The corporate volunteers can also access the Flood Disaster Inquiry and Notification System introduced in the empirical study case in Section 4.1. For private individuals, since there is no such feedback regarding the relationships between system quality and information quality, the information gathered will not be strengthen.

\subsection{Contribution of This Research to Extant Literature and Future Research Possibilities}

Regarding to the contribution, corporate volunteer partnerships with non-profit organizations have progressively developed in real world over the last ten years. The corporate volunteer programs have been described as one of the fastest-growing areas of voluntary activity, with North America as the market leader and with a rising interest in Western European countries. Over 90 percent of Fortune 500 companies run employee volunteer programs, formally sponsoring and subsidizing employees' efforts to perform community service and outreach activities on company time [105]. However, this field is still in its infancy and limited in magnitude. Most literatures are in the disciplines of business, management, and ethics. Researchers have emphasized a strong employee-centered and business focus and a narrow geographic spread [105]. This study focused on a developing country in Asia, because the public sector's resources are limited, and most firms are small-to-medium enterprises. Compared to the focus on financial services from Fortune 500 companies in North America and Western Europe, this study demonstrated an alternative viewpoint regarding the feasibility of integration of the corporate volunteers, as well as the firm's IT resources.

Besides, literature has strongly advised nonprofits developing strategies for successful cooperation with companies [106]. The management tools used by corporate volunteers could increase professionalism of nonprofits; thus far, the nonprofits studied have hardly developed any strategies for corporate volunteers [107]. The Public Flood Disaster Inquiry and Notification System is a useful communication tool between corporate volunteers and public sectors. The analysis of key influence factors based on successful information model may offer nonprofits effective communication strategies for coping with corporate volunteers. 
Most of the past works have focused on the roles of corporate volunteers in corporate social responsibility. Future research possibilities include comparing the flood data collected by corporate volunteers and individual volunteers. Furthermore, evaluations of motivations and the quality of the data collected by corporate volunteers and individual volunteers might enable a continuous optimization of all projects and of a corporate volunteer strategy.

\section{Concluding Remarks}

The definition, configuration, and reconfiguration of flood disaster inquiry and notification systems are critical, attracting tremendous interest from policy-makers and researchers. In this study, we developed a decision support system to enable the integration of corporate volunteers into flood disaster inquiry and notification systems. The decision framework has further been verified as feasible based on the opinions provided by Taiwanese experts. The combination of theoretical and practical considerations in the proposed decision framework has important implications for both academics and practitioners in gaining a better understanding of the factors influencing the integration of corporate volunteers into public disaster inquiry and notification systems.

In the past, numerous studies have been conducted in the field of flood disaster detection, inquiry, and notification systems. Although corporate volunteers can play a crucial role in enhancing the efficiency and effectiveness of delivering disaster information in various disaster management contexts, studies on corporate volunteers in disaster management systems are limited. This work is the first academic research project related to the integration of corporate volunteers into public emergency management systems through adopting the information system success model and the PPP. This research further extends the existing studies by applying social science research to natural hazard threats preventions, demonstrating the partnership between corporate volunteers and the government. With the well-verified theoretical framework, a new research field of public participation in disaster management can be created.

Practically, the key objective of government flood disaster departments is to conduct overall flood disaster assessments immediately. The integration of corporate volunteers into the public flood disaster inquiry and notification system can improve the information quality. Our research results indicated that corporate volunteers can provide timely and accurate information to fill the traditional gap in flood disaster mitigation by government institutes only. Further, the analytic results can help define strategies to enhance the participation of corporate volunteers in the disaster inquiry and mitigation system, and further enhance the system's satisfaction, reducing the cost of flood information collection and increasing decision-making effectiveness and efficiency. The experiences of the incorporations of corporate volunteers into the public flood disaster inquiry and notification systems that are emerging can also serve as the basis for other countries to incorporate corporate volunteers into the public flood disaster inquiry and notification systems.

Finally, flood disaster management problems are inherently complex, time-bound, and multi-faceted. Such problems involve many decision-makers, have high stakes and limited technical information, and result in difficult tradeoffs. The hybrid MCDM-based analytic framework can solve these problems and contribute to more effective disaster management. Since the available resources of most government flood disaster management departments are limited, the research results and prioritizing improvements in system and information quality can serve as the basis for system improvement in the future. Our results can also serve as the basis for public policy definitions. The proposed multi-criteria decision support instruments can enhance communication among stakeholders, such as the administrators from the public sector, corporate management, and information system providers. The PPPs can also be improved accordingly, though the availability of resources is very limited. In the future, the framework can help improve flood disaster information inquiry and notification performance under a limited budget, increasing decision-making effectiveness, efficiency, and transparency. 
Author Contributions: M.-C.S. and C.-L.Y. conducted the observations and designed research. C.-L.Y. and C.-Y.H. performed research, analyzed the data, and wrote the paper.

Acknowledgments: We thank Taiwanese Water Resources Agency of Ministry of Economic Affairs' staff for inspiring conversations, suggestions, and feedback in preparing this article.

Conflicts of Interest: The authors declare no conflict of interest.

\section{Appendix A. DEMATEL}

The following are explanations of the DEMATEL formulas based on Tzeng and Huang [89], as well as Yang et al. [90].

Step 1: Build an initial direct-relation matrix

Experts are asked to indicate the direct influence degree between factor $i$ and factor $j$, as indicated by $a_{i j}$, using a pair-wise comparison scale designated with five levels. The initial direct-relation matrix $A$ is obtained by deriving the influence relationships between criteria through Equation (A1).

$$
A=\left[\begin{array}{ccccc}
a_{11} & \cdots & a_{1 j} & \cdots & a_{1 n} \\
\vdots & & \vdots & & \vdots \\
a_{i 1} & \cdots & a_{i j} & \cdots & a_{i n} \\
\vdots & & \vdots & & \vdots \\
a_{n 1} & \cdots & a_{n j} & \cdots & a_{n n}
\end{array}\right]
$$

$a_{i j}$ is denoted as the degree to which the $i$ th objective affects the $j$ th objective.

Step 2: Normalize the direct-relation matrix

The normalized direct-relation matrix $N$ is obtained through Equation (A2).

$$
N=y \boldsymbol{A}, y=\min \left\{1 / \max _{i} \sum_{j=1}^{n} a_{i j}, 1 / \max _{j} \sum_{i=1}^{n} a_{i j}\right\}, i, j \in\{1,2, \ldots, n\} .
$$

Step 3: Build the total relation matrix $T$.

The total-relation matrix $\boldsymbol{T}$ is acquired by Equation (A3):

$$
\begin{aligned}
T & =\boldsymbol{N}+\boldsymbol{N}^{2}+\boldsymbol{N}^{3}+\ldots+\boldsymbol{N}^{\varepsilon} \\
& =\boldsymbol{N}\left(\boldsymbol{I}+\boldsymbol{N}+\boldsymbol{N}^{2}+\ldots+\boldsymbol{N}^{\varepsilon-1}\right)(\boldsymbol{I}-\boldsymbol{N})(\boldsymbol{I}-\boldsymbol{N})^{-\mathbf{1}} \\
& =\boldsymbol{N}\left(\boldsymbol{I}-\boldsymbol{N}^{\varepsilon}\right)(\boldsymbol{I}-\boldsymbol{N})^{-\mathbf{1}} \\
& =\boldsymbol{N}(\boldsymbol{I}-\boldsymbol{N})^{-1}, \text { when } \varepsilon \rightarrow \infty, \boldsymbol{N}^{\varepsilon}=[0]_{n \times n}
\end{aligned}
$$

in which $\varepsilon \rightarrow \infty, I$ is the identity matrix.

Step 4: Compute the influence strength of the factors

Aggregate the values of the rows and columns in matrix $T$ to obtain a value $r$ and $c$ through the Equations (A4) and (A5), respectively. Thus, $r_{i}$ presents the sum of the influences dispatching from factor $i$ to the other factors. The $c_{j}$ is the column sum of the $j$ th column of matrix $T$.

$$
\begin{aligned}
& \mathbf{T}=\left[t_{i j}\right], i, j \in\{1,2, \ldots n\} \\
& \mathrm{r}=\left[r_{i}\right]_{n \times 1}=\left(\sum_{j=1}^{n} t_{i j}\right)_{n \times 1}
\end{aligned}
$$




$$
c=\left[c_{j}\right]_{n \times 1}=\left(\sum_{i=1}^{n} t_{i j}\right)^{\prime} 1 \times n
$$

Step 5: Produce a causal diagram

A causal diagram can be acquired by mapping a data set $\left(r_{i}+c_{i}, r_{i}-c_{i}\right)$. The value of $r_{i}+c_{i}$ indicates the strength of influence given and received. The higher the value of $r_{i}+c_{i}$ a factor has, the more related it is to the other factors. Similarly, the value of $r_{i}-c_{i}$ indicates the causal relationship between factors. If $r_{i}-c_{i}$ is positive, then the factor is a "cause factor", dispatching influence to the others. If $r_{i}-c_{i}$ is negative, the factor is an "effect factor", receiving influence from others. The higher the value of $r_{i}-c_{i}$ a factor has, the more influence it has on the other factors, and hence this factor is presumed to have a higher priority than the others. In other words, the lower the value of $r_{i}-c_{i}$ a factor has, the greater its received influence from the other factors, and, consequently, the lower the priority it is assumed to have [89].

Step 6: Set a threshold value and obtain the Network Relation Map (NRM)

The visualization of all of the network of determinates form matrix $T$ is too complex to extract valuable information. It is necessary to set a threshold value $\alpha$ for the influence level to filter out minor effects. The influence value in matrix $T$ is higher than the threshold value that will be chosen and converted into the NRM. The threshold value can be decided by the experts. When the threshold value and the relative NRM have been decided, the NRM can be drawn accordingly.

\section{Appendix B. Analytic Network Process (ANP)}

The following are explanations of the ANP formulas based on Saaty [75] and Yang et al. [91].

Step 7: Build an unweighted supermatrix through pairwise comparisons

The original supermatrix of column eigenvectors is obtained from pairwise comparison matrices of elements. The $\boldsymbol{C}_{h}$ denotes the nth cluster, $e_{n m}$ denotes the $m$ th criterion in the $n$th cluster, and $W_{i j}$ in the supermatrix is a principal eigenvector of the influence of the elements in the $i$ th component of the network on an element in the $j$ th component. In addition, if the $j$ th cluster has no influence on the ith cluster, then $W_{i j}=[0]$.

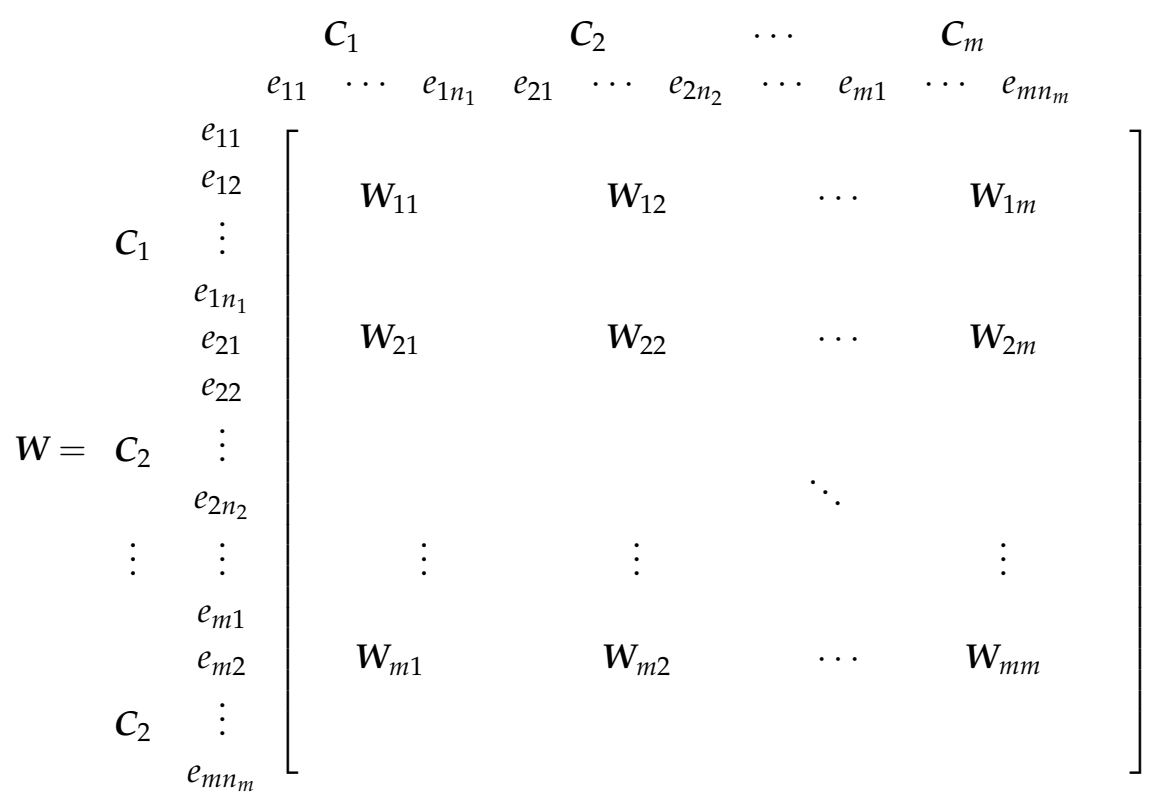

Step 8: Obtain the weighted supermatrix by multiplying the normalized matrix 
After forming the supermatrix, the weighted supermatrix is derived by transforming all columns sum to unity exactly. The weighted supermatrix is raised to limiting powers, such as Equation (A7), to get the global priority vector or called weights.

$$
\lim _{\theta \rightarrow \infty} W^{\theta}
$$

In addition, if the supermatrix has the effect of cyclicity, the limiting supermatrix is not the only one. There are two or more limiting supermatrices in this situation, and the Cesaro sum would need to be calculated to get the priority. The Cesaro sum is formulated as follows.

$$
\lim _{\psi \rightarrow \infty}\left(\frac{1}{v}\right) \sum_{j=1}^{v} \boldsymbol{W}_{j}^{\psi}
$$

to calculate the average effect of the limiting supermatrix (i.e., the average priority weights) in which $W_{j}$ denotes the $j$ th limiting supermatrix.

\section{Appendix C. The Detailed Calculation Procedures of the DEMATEL}

Total relation matrix $T_{\text {dimensions }}$ of dimensions:

$$
T_{\text {dimensions }}=\left[\begin{array}{cccccc}
0.906 & 1.073 & 1.056 & 1.093 & 1.082 & 1.012 \\
1.001 & 0.827 & 0.965 & 1.006 & 0.997 & 0.920 \\
0.933 & 0.910 & 0.760 & 0.938 & 0.913 & 0.883 \\
0.915 & 0.931 & 0.903 & 0.790 & 0.924 & 0.862 \\
0.872 & 0.860 & 0.846 & 0.882 & 0.741 & 0.836 \\
0.793 & 0.775 & 0.769 & 0.811 & 0.820 & 0.637
\end{array}\right]
$$

Total relation matrix $T_{a}$ of factors:

$$
T_{a}=\left[\begin{array}{llll}
2.994 & 3.228 & 3.142 & 2.844 \\
3.136 & 2.816 & 2.991 & 2.722 \\
2.935 & 2.877 & 2.609 & 2.596 \\
2.862 & 2.814 & 2.784 & 2.323
\end{array}\right]
$$

Total relation matrix $T_{b}$ of factors:

$$
T_{b}=\left[\begin{array}{cccc}
4.942 & 5.054 & 4.935 & 5.053 \\
5.457 & 5.077 & 5.222 & 5.326 \\
5.154 & 5.011 & 4.686 & 5.016 \\
5.530 & 5.390 & 5.268 & 5.134
\end{array}\right]
$$

Total relation matrix $T_{\mathcal{C}}$ of factors:

$$
T_{\mathcal{c}}=\left[\begin{array}{lll}
15.279 & 15.542 & 15.682 \\
15.535 & 15.128 & 15.609 \\
15.012 & 14.930 & 14.759
\end{array}\right]
$$

Total relation matrix $T_{d}$ of factors:

$$
T_{d}=\left[\begin{array}{lllll}
1.992 & 2.189 & 2.188 & 2.091 & 1.843 \\
2.122 & 1.889 & 2.097 & 1.984 & 1.746 \\
1.945 & 1.914 & 1.750 & 1.830 & 1.636 \\
2.040 & 2.034 & 2.033 & 1.742 & 1.699 \\
1.824 & 1.828 & 1.834 & 1.713 & 1.391
\end{array}\right]
$$


Total relation matrix $T_{e}$ of factors.

$$
T_{e}=\left[\begin{array}{lllll}
2.525 & 2.704 & 2.455 & 2.395 & 2.504 \\
2.685 & 2.406 & 2.390 & 2.330 & 2.429 \\
2.643 & 2.573 & 2.185 & 2.300 & 2.408 \\
2.558 & 2.509 & 2.326 & 2.080 & 2.364 \\
2.338 & 2.293 & 2.115 & 2.066 & 1.986
\end{array}\right]
$$

Total relation matrix $T_{f}$ of factors.

$$
T_{f}=\left[\begin{array}{lll}
13.364 & 14.169 & 13.979 \\
13.409 & 13.552 & 13.692 \\
13.591 & 14.076 & 13.552
\end{array}\right]
$$

\begin{tabular}{|c|c|c|c|c|c|c|c|c|c|c|c|c|c|}
\hline Dimensions & \multicolumn{2}{|c|}{$\bar{A}$} & \multicolumn{2}{|c|}{ B } & \multicolumn{2}{|c|}{ C } & \multicolumn{2}{|c|}{ D } & \multicolumn{2}{|c|}{ E } & \multicolumn{3}{|c|}{ F } \\
\hline$r_{i}+c_{i}$ & \multicolumn{2}{|c|}{11.644} & \multicolumn{2}{|c|}{11.091} & \multicolumn{2}{|c|}{10.636} & \multicolumn{2}{|c|}{10.846} & \multicolumn{2}{|c|}{10.514} & \multicolumn{3}{|c|}{9.754} \\
\hline$r_{i}-c_{i}$ & \multicolumn{2}{|c|}{0.802} & \multicolumn{2}{|c|}{0.341} & \multicolumn{2}{|c|}{0.036} & \multicolumn{2}{|c|}{-0.194} & \multicolumn{2}{|c|}{-0.440} & \multicolumn{2}{|c|}{-0.545} & \\
\hline Factors & $a_{1}$ & $a_{2}$ & $a_{3}$ & $a_{4}$ & $b_{1}$ & $b_{2}$ & $b_{3}$ & $b_{4}$ & $c_{1}$ & $c_{2}$ & $c_{3}$ & & \\
\hline$r_{i}+c_{i}$ & 24.132 & 23.401 & 22.544 & 21.266 & 41.066 & 41.614 & 39.979 & 41.851 & 92.329 & 91.873 & 90.751 & & \\
\hline$r_{i}-c_{i}$ & 0.281 & -0.071 & -0.509 & 0.299 & -1.099 & 0.550 & -0.244 & 0.793 & 0.677 & 0.671 & -1.349 & & \\
\hline Factors & $d_{1}$ & $d_{2}$ & $d_{3}$ & $d_{4}$ & $d_{5}$ & $e_{1}$ & $e_{2}$ & $e_{3}$ & $e_{4}$ & $e_{5}$ & $f_{1}$ & $f_{2}$ & $f_{3}$ \\
\hline$r_{i}+c_{i}$ & 20.228 & 19.693 & 18.978 & 18.908 & 16.905 & 25.331 & 24.725 & 23.580 & 23.008 & 22.489 & 81.876 & 82.450 & 82.442 \\
\hline$r_{i}-c_{i}$ & 0.379 & -0.018 & -0.826 & 0.189 & 0.276 & -0.166 & -0.244 & 0.638 & 0.665 & -0.894 & 1.149 & -1.145 & -0.004 \\
\hline
\end{tabular}

Table A1. $r_{i}+c_{i}$ and $r_{i}-c_{i}$ values calculated from the direct/indirect matrix T. 


\section{Appendix D. The Detailed Calculation Procedures of the ANP}

Weighted supermatrix $\boldsymbol{W}_{c}$ :

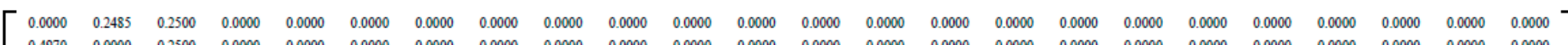

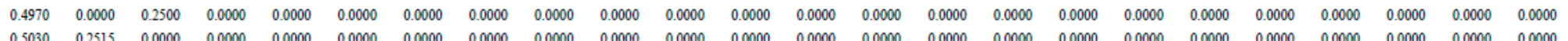

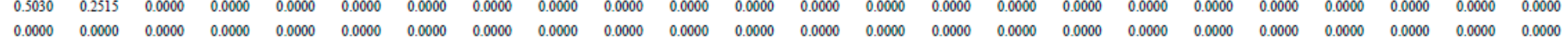
$\begin{array}{llllllllllllllllllllllll}0.0000 & 0.0000 & 0.0000 & 0.0000 & 0.0000 & 0.0000 & 0.0000 & 0.0000 & 0.0000 & 0.0000 & 0.0000 & 0.0000 & 0.00000 & 0.0000 & 0.0000 & 0.0000 & 0.0000 & 0.0000 & 0.0000 & 0.0000 & 0.0000 & 0.0000 & 0.00000 & 0.00000 \\ 0.0000 & 0.0000 & 0.0000 & 0.0000 & 0.0000 & 0.2531 & 0.0000 & 0.2627 & 0.0000 & 0.0000 & 0.0000 & 0.0000 & 0.0000 & 0.0000 & 0.0000 & 0.0000 & 0.0000 & 0.0000 & 0.0000 & 0.0000 & 0.0000 & 0.0000 & 0.0000 & 0.0000\end{array}$

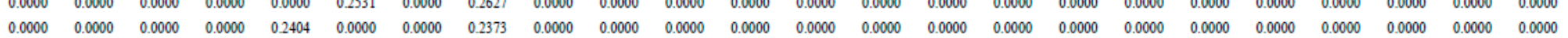
\begin{tabular}{lllllllllllllllllllllllll}
0.0000 & 0.0000 & 0.0000 & 0.0000 & 0.0000 & 0.0000 & 0.00000 & 0.0000 & 0.0000 & 0.0000 & 0.0000 & 0.0000 & 0.00000 & 0.0000 & 0.0000 & 0.0000 & 0.00000 & 0.0000 & 0.00000 & 0.00000 & 0.00000 & 0.00000 & 0.00000 & 0.00000 \\
\hline
\end{tabular}

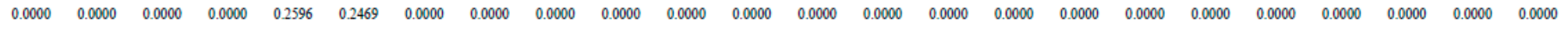
$\begin{array}{llllllllllllllllllllllll}0.0000 & 0.0000 & 0.0000 & 0.0000 & 0.0000 & 0.0000 & 0.0000 & 0.0000 & 0.0000 & 0.3026 & 0.1554 & 0.1620 & 0.0000 & 0.0000 & 0.0000 & 0.0000 & 0.0000 & 0.0000 & 0.0000 & 0.0000 & 0.0000 & 0.0000 & 0.0000 & 0.0000\end{array}$

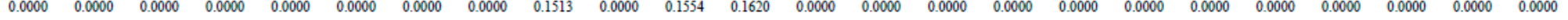

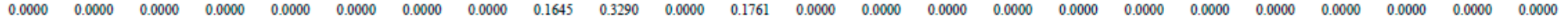
$\begin{array}{llllllllllllllllllllllll}0.0000 & 0.0000 & 0.0000 & 0.0000 & 0.0000 & 0.0000 & 0.0000 & 0.0000 & 0.1842 & 0.3685 & 0.1893 & 0.0000 & 0.0000 & 0.0000 & 0.0000 & 0.0000 & 0.0000 & 0.0000 & 0.0000 & 0.0000 & 0.0000 & 0.0000 & 0.0000 & 0.0000\end{array}$ $\begin{array}{llllllllllllllllllllllll}0.0000 & 0.0000 & 0.0000 & 0.0000 & 0.0000 & 0.0000 & 0.0000 & 0.0000 & 0.0000 & 0.0000 & 0.0000 & 0.0000 & 0.0000 & 0.0000 & 0.0000 & 0.0000 & 0.0000 & 0.0000 & 0.0000 & 0.0000 & 0.0000 & 0.0000 & 0.0000 & 0.0000\end{array}$

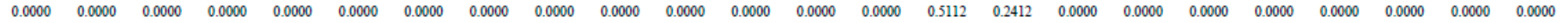

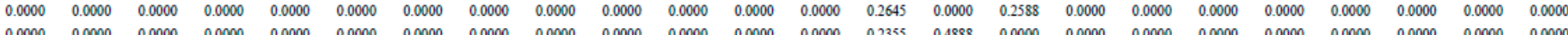

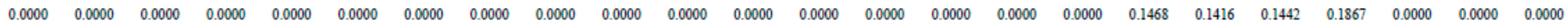

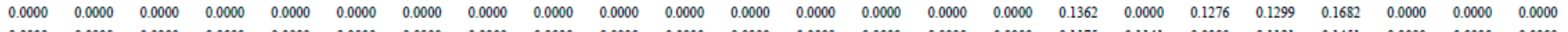
$\begin{array}{llllllllllllllllllllllll}0.0000 & 0.0000 & 0.0000 & 0.0000 & 0.0000 & 0.0000 & 0.0000 & 0.0000 & 0.0000 & 0.0000 & 0.0000 & 0.0000 & 0.0000 & 0.0000 & 0.0000 & 0.0000 & 0.1175 & 0.1141 & 0.0000 & 0.1121 & 0.1451 & 0.0000 & 0.0000 & 0.00000 \\ 0\end{array}$

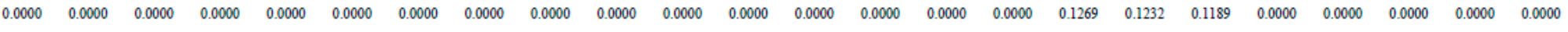

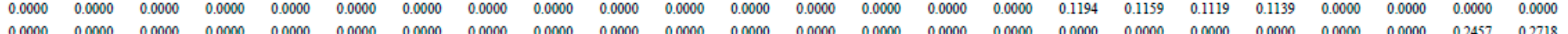

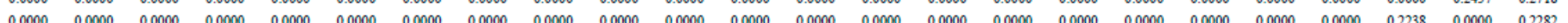

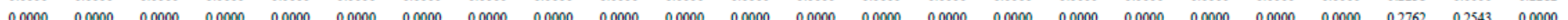

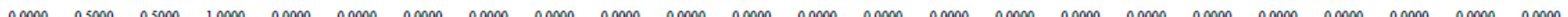

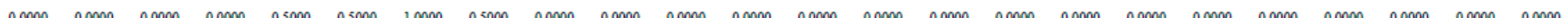

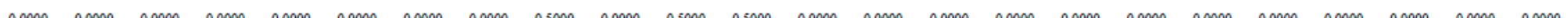

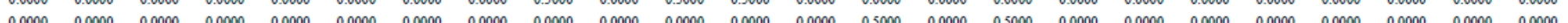

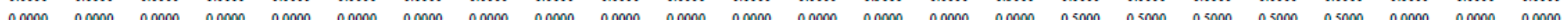
$\left.\begin{array}{llllllllllllllllllllllll}0.0000 & 0.0000 & 0.0000 & 0.0000 & 0.0000 & 0.0000 & 0.0000 & 0.0000 & 0.0000 & 0.00000 & 0.0000 & 0.0000 & 0.0000 & 0.0000 & 0.0000 & 0.0000 & 0.5000 & 0.5000 & 0.5000 & 0.5000 & 0.5000 & 0.0000 & 0.0000 & 0.00000 \\ 0.0000 & 0.0000 & 0.0000 & 0.0000 & 0.0000 & 0.0000 & 0.0000 & 0.0000 & 0.0000 & 0.0000 & 0.0000 & 0.0000 & 0.0000 & 0.0000 & 0.0000 & 0.0000 & 0.0000 & 0.0000 & 0.0000 & 0.0000 & 0.0000 & 0.5000 & 0.5000 & 0.5000\end{array}\right]$ 


\section{Limited supermatrix $W_{c}^{*}$ :}

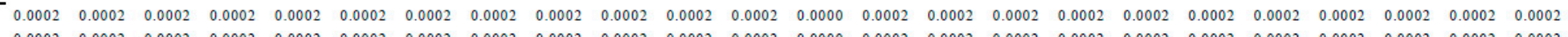

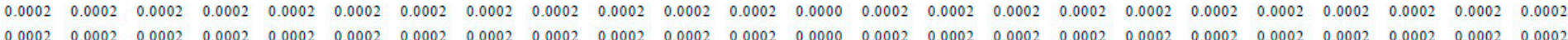
$\begin{array}{lllllllllllllllllllllllll}0.00000 & 0.0000 & 0.0000 & 0.0000 & 0.0000 & 0.0000 & 0.0000 & 0.0000 & 0.0000 & 0.0000 & 0.0000 & 0.00000 & 0.0000 & 0.0000 & 0.0000 & 0.0000 & 0.0002 & 0.0002 & 0.0002 & 0.0002 & 0.0002 & 0.0002 & 0.0002 & 0.00002 \\ 0.0000 & 0.0000 & 0.0000 & 0.0000 & 0.0000 & 0.0000 & 0.00000\end{array}$ $\begin{array}{llllllllllllllllllllllllll}0.0000 & 0.0000 & 0.0000 & 0.0000 & 0.0000 & 0.0000 & 0.0000 & 0.0000 & 0.0000 & 0.0000 & 0.0000 & 0.0000 & 0.0000 & 0.0000 & 0.0000 & 0.0000 & 0.0000 & 0.0000 & 0.0000 & 0.0000 & 0.0000 & 0.0000 & 0.0000 & 0.0000\end{array}$

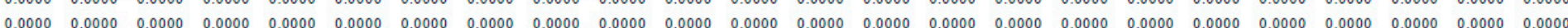

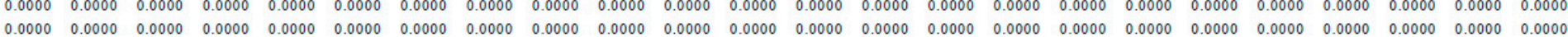

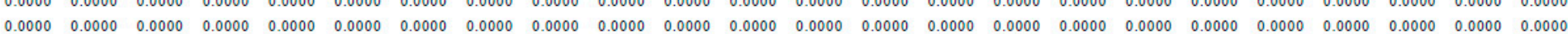
$\begin{array}{llllllllllllllllllllllll}0.0003 & 0.0003 & 0.0003 & 0.0003 & 0.0003 & 0.0003 & 0.0003 & 0.0003 & 0.0003 & 0.0003 & 0.0003 & 0.0003 & 0.0000 & 0.0003 & 0.0003 & 0.0003 & 0.0003 & 0.0003 & 0.0003 & 0.0003 & 0.0003 & 0.0003 & 0.0003 & 0.00003\end{array}$

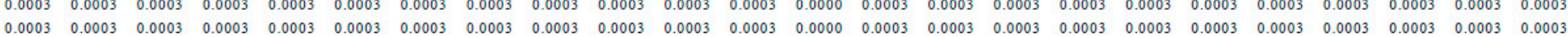
$\begin{array}{lllllllllllllllllllllllllllll}0.0004 & 0.0004 & 0.0004 & 0.0004 & 0.0004 & 0.0004 & 0.0004 & 0.0004 & 0.0004 & 0.0004 & 0.0004 & 0.0004 & 0.0000 & 0.0004 & 0.0004 & 0.0004 & 0.0004 & 0.0004 & 0.0004 & 0.0004 & 0.0004 & 0.0004 & 0.0004 & 0.00004\end{array}$ $\begin{array}{lllllllllllllllllllllllllllll}0.0004 & 0.0004 & 0.0004 & 0.0004 & 0.0004 & 0.0004 & 0.0004 & 0.0004 & 0.0004 & 0.0004 & 0.0004 & 0.0004 & 0.0000 & 0.0004 & 0.0004 & 0.0004 & 0.0004 & 0.0004 & 0.0004 & 0.0004 & 0.0004 & 0.0004 & 0.00004 & 0.00004\end{array}$ $\begin{array}{llllllllllllllllllllllllllllllllll}0.0001 & 0.0001 & 0.0001 & 0.0001 & 0.0001 & 0.0001 & 0.0001 & 0.0001 & 0.0001 & 0.0001 & 0.0001 & 0.0001 & 0.0000 & 0.0001 & 0.0001 & 0.0001 & 0.0001 & 0.0001 & 0.0001 & 0.00001 & 0.0001 & 0.0001 & 0.0001 & 0.0001 \\ 0\end{array}$ $\begin{array}{llllllllllllllllllllllll}0.1600 & 0.1600 & 0.1600 & 0.1600 & 0.1600 & 0.1600 & 0.1600 & 0.1600 & 0.1600 & 0.1600 & 0.1600 & 0.1600 & 0.0000 & 0.1609 & 0.1609 & 0.1609 & 0.1590 & 0.1590 & 0.1590 & 0.1590 & 0.1590 & 0.1600 & 0.1600 & 0.1600\end{array}$

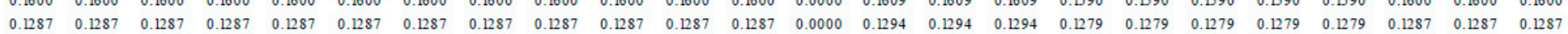

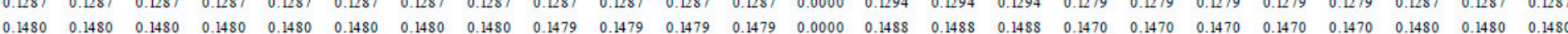
$\begin{array}{lllllllllllllllllllllllll}0.0634 & 0.0634 & 0.0634 & 0.0634 & 0.0634 & 0.0634 & 0.0634 & 0.0634 & 0.0634 & 0.0634 & 0.0634 & 0.0634 & 0.0000 & 0.0628 & 0.0628 & 0.0628 & 0.0640 & 0.0640 & 0.0640 & 0.0640 & 0.0640 & 0.0634 & 0.0634 & 0.0634\end{array}$ $\begin{array}{lllllllllllllllllllllllll}0.0581 & 0.0581 & 0.0581 & 0.0581 & 0.0581 & 0.0581 & 0.0581 & 0.0581 & 0.0581 & 0.0581 & 0.0581 & 0.0581 & 0.0000 & 0.0576 & 0.0576 & 0.0576 & 0.0586 & 0.0586 & 0.0586 & 0.0586 & 0.0586 & 0.0581 & 0.0581 & 0.0581\end{array}$ \begin{tabular}{llllllllllllllllllllllllll}
0.0511 & 0.0511 & 0.0511 & 0.0511 & 0.0511 & 0.0511 & 0.0511 & 0.0511 & 0.0511 & 0.0511 & 0.0511 & 0.0511 & 0.0000 & 0.0507 & 0.0507 & 0.0507 & 0.0516 & 0.0516 & 0.0516 & 0.0516 & 0.0516 & 0.0511 & 0.0511 & 0.0511 \\
\hline
\end{tabular} $\begin{array}{lllllllllllllllllllllllll}0.0476 & 0.0476 & 0.0476 & 0.0476 & 0.0476 & 0.0476 & 0.0476 & 0.0476 & 0.0476 & 0.0476 & 0.0476 & 0.0476 & 0.0000 & 0.0472 & 0.0472 & 0.0472 & 0.0480 & 0.0480 & 0.0480 & 0.0480 & 0.0480 & 0.0476 & 0.0476 & 0.0476\end{array}$ $\begin{array}{llllllllllllllllllllllll}0.0502 & 0.0502 & 0.0502 & 0.0502 & 0.0502 & 0.0502 & 0.0502 & 0.0502 & 0.0502 & 0.0502 & 0.0502 & 0.0502 & 0.0000 & 0.0498 & 0.0498 & 0.0498 & 0.0507 & 0.0507 & 0.0507 & 0.0507 & 0.0507 & 0.0502 & 0.0502 & 0.0502 \\ 0\end{array}$

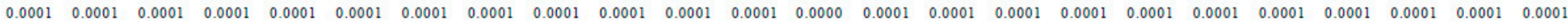
$\begin{array}{llllllllllllllllllllllll}0.0001 & 0.0001 & 0.0001 & 0.0001 & 0.0001 & 0.0001 & 0.0001 & 0.0001 & 0.0001 & 0.0001 & 0.0001 & 0.0001 & 0.0000 & 0.0001 & 0.0001 & 0.0001 & 0.0001 & 0.0001 & 0.0001 & 0.0001 & 0.0001 & 0.0001 & 0.0001 & 0.0001\end{array}$ $\begin{array}{lllllllllllllllllllllllll}0.0001 & 0.0001 & 0.0001 & 0.0001 & 0.0001 & 0.0001 & 0.0001 & 0.0001 & 0.0001 & 0.0001 & 0.0001 & 0.0001 & 0.0000 & 0.0001 & 0.0001 & 0.0001 & 0.0001 & 0.0001 & 0.0001 & 0.0001 & 0.0001 & 0.0001 & 0.0001 & 0.0001 \\ 0\end{array}$ \begin{tabular}{llllllllllllllllllllllll}
0.0003 & 0.0003 & 0.0003 & 0.0003 & 0.0003 & 0.0003 & 0.0003 & 0.0003 & 0.0003 & 0.0003 & 0.0003 & 0.0003 & 0.0000 & 0.0003 & 0.0003 & 0.0003 & 0.0003 & 0.0003 & 0.0003 & 0.0003 & 0.0003 & 0.0003 & 0.0003 & 0.0003 \\
\hline
\end{tabular} $\begin{array}{llllllllllllllllllllllllllll}0.0001 & 0.0001 & 0.0001 & 0.0001 & 0.0001 & 0.0001 & 0.0001 & 0.0001 & 0.0001 & 0.0001 & 0.0001 & 0.0001 & 0.0000 & 0.0001 & 0.0001 & 0.0001 & 0.0001 & 0.0001 & 0.0001 & 0.0001 & 0.0001 & 0.0001 & 0.0001 & 0.0001\end{array}$

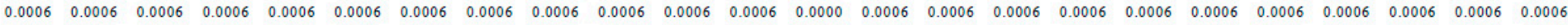
$\begin{array}{llllllllllllllllllllllll}0.1540 & 0.1540 & 0.1540 & 0.1540 & 0.1540 & 0.1540 & 0.1540 & 0.1540 & 0.1540 & 0.1540 & 0.1540 & 0.1540 & 0.0000 & 0.1549 & 0.1549 & 0.1549 & 0.1530 & 0.1530 & 0.1530 & 0.1530 & 0.1530 & 0.1540 & 0.1540 & 0.1540\end{array}$ $\left.\begin{array}{llllllllllllllllllllllll}0.1352 & 0.1352 & 0.1352 & 0.1352 & 0.1352 & 0.1352 & 0.1352 & 0.1352 & 0.1352 & 0.1352 & 0.1352 & 0.1352 & 0.0000 & 0.1341 & 0.1341 & 0.1341 & 0.1365 & 0.1365 & 0.1365 & 0.1365 & 0.1365 & 0.1352 & 0.1352 & 0.1352 \\ 0.0003 & 0.003 & 0.003 & 0.000 & 0.0003 & 0.0003 & 0.3003 & 0.0003 & 0.0003 & 0.0003 & 0.0003 & 0.0003 & 0.0000 & 0.0003 & 0.0003 & 0.0003 & 0.003 & 0.0003 & 0.0003 & 0.0003 & 0.0003 & 0.003 & 0.0003 & 0.0003\end{array}\right]$ 


\section{References}

1. Sodhi, M.S.; Tang, C.S. Buttressing supply chains against floods in Asia for humanitarian relief and economic recovery. Prod. Oper. Manag. 2014, 23, 938-950. [CrossRef]

2. Levy, J.K.; Hartmann, J.; Li, K.W.; An, Y.; Asgary, A. Multi-Criteria Decision Support Systems for Flood Hazard Mitigation and Emergency Response in Urban Watersheds1. JAWRA 2007, 43, 346-358.

3. Bubeck, P.; Botzen, W.J.; Aerts, J.C. A review of risk perceptions and other factors that influence flood mitigation behavior. Risk Anal. 2012, 32, 1481-1495. [CrossRef] [PubMed]

4. Hirabayashi, Y.; Mahendran, R.; Koirala, S.; Konoshima, L.; Yamazaki, D.; Watanabe, S.; Kim, H.; Kanae, S. Global flood risk under climate change. Nat. Clim. Chang. 2013, 3, 816-821. [CrossRef]

5. Aerts, J.C.; Botzen, W.W.; Emanuel, K.; Lin, N.; de Moel, H.; Michel-Kerjan, E.O. Evaluating flood resilience strategies for coastal megacities. Science 2014, 344, 473-475. [CrossRef] [PubMed]

6. Wahlstrom, M.; Guha-Sapir, D. The Human Cost of Weather-Related Disasters 1995-2015; United Nations International Strategy for Disaster Reduction: Geneva, Switzerland, 2015.

7. Arkema, K.K.; Guannel, G.; Verutes, G.; Wood, S.A.; Guerry, A.; Ruckelshaus, M.; Kareiva, P.; Lacayo, M.; Silver, J.M. Coastal habitats shield people and property from sea-level rise and storms. Nat. Clim. Chang. 2013, 3, 913-918. [CrossRef]

8. Kundzewicz, Z.W. Flood protection-Sustainability issues. Hydrol. Sci. J. 1999, 44, 559-571. [CrossRef]

9. Hutton, R.B.; Cox, D.B.; Clouse, M.L.; Gaensbauer, J.; Banks, B.D. The role of sustainable development in risk assessment and management for multinational corporations. Multinatl. Bus. Rev. 2007, 15, 89-111. Available online: https:/ / www.scheller.gatech.edu/centers-initiatives/ciber/projects/workingpaper/2007/ 013-07-08.pdf (accessed on 11 June 2018).

10. Plate, E.J. Flood risk and flood management. J. Hydrol. 2002, 267, 2-11. [CrossRef]

11. Poussin, J.; Bubeck, P.; Aerts, J.; Ward, P. Potential of semi-structural and non-structural adaptation strategies to reduce future flood risk: Case study for the Meuse. Nat. Hazards Earth Syst. Sci. 2012, 12, 3455-3471. [CrossRef]

12. Col, J.M. Managing disasters: The role of local government. Public Adm. Rev. 2007, 67, 114-124. [CrossRef]

13. Werritty, A. Sustainable flood management: Oxymoron or new paradigm? Area 2006, 38, 16-23. [CrossRef]

14. Ahmadisharaf, E.; Kalyanapu, A.J.; Chung, E.-S. Sustainability-Based Flood Hazard Mapping of the Swannanoa River Watershed. Sustainability 2017, 9, 1735. [CrossRef]

15. Poser, K.; Dransch, D. Volunteered geographic information for disaster management with application to rapid flood damage estimation. Geomatica 2010, 64, 89-98.

16. McDougall, K. Using volunteered information to map the Queensland floods. In Proceedings of the 2011 Surveying and Spatial Sciences Conference: Innovation in Action: Working Smarter (SSSC 2011), Wellington, New Zealand, 21-25 November 2011; pp. 13-23.

17. Ranke, U. Natural Disaster Risk Management: Geosciences and Social Responsibility; Springer International Publishing: New York, NY, USA, 2015.

18. Gatignon-Turnau, A.-L.; Mignonac, K. Using employee volunteering for public relations: Implications for corporate volunteers' organizational commitment. J. Bus. Res. 2015, 68, 7-18. [CrossRef]

19. Allen, K. The big tent. In Corporate Volunteering in the Global Age; Editorial Ariel, SA; Fundación Telefónica: Madrid, Spain, 2012.

20. Fontela, E.; Gabus, A. The DEMATEL Observer; Battelle Geneva Research Center: Geneva, Switzerland, 1976.

21. Division of Flood Management. A Guide for Developing a Pre-flood Hazard Mitigation Plan for California Communities: Planning, the Key to Reducing Flood Damage; Division of Flood Management, Federal Emergency Management Agency, U.S.: White Mountains, CA, USA, 1985.

22. Brody, S.D.; Kang, J.E.; Bernhardt, S. Identifying factors influencing flood mitigation at the local level in Texas and Florida: The role of organizational capacity. Nat. Hazards 2010, 52, 167-184. [CrossRef]

23. UNISDR. Terminology on Disaster Risk Reduction; UNISDR: Geneva, Switzerland, 2009.

24. Botzen, W.; Aerts, J.; Van Den Bergh, J. Dependence of flood risk perceptions on socioeconomic and objective risk factors. Water Resour. Res. 2009, 45. [CrossRef]

25. Raaijmakers, R.; Krywkow, J.; van der Veen, A. Flood risk perceptions and spatial multi-criteria analysis: An exploratory research for hazard mitigation. Nat. Hazards 2008, 46, 307-322. [CrossRef]

26. Van de Walle, B.; Turoff, M.; Hiltz, S.R. Information Systems for Emergency Management; Routledge: London, UK, 2014. 
27. Shan, S.; Wang, L.; Li, L.; Chen, Y. An emergency response decision support system framework for application in e-government. Inf. Technol. Manag. 2012, 13, 411-427. [CrossRef]

28. Dawson, R.J.; Ball, T.; Werritty, J.; Werritty, A.; Hall, J.W.; Roche, N. Assessing the effectiveness of non-structural flood management measures in the Thames Estuary under conditions of socio-economic and environmental change. Glob. Environ. Chang. 2011, 21, 628-646. [CrossRef]

29. Dargie, W.; Poellabauer, C. Fundamentals of Wireless Sensor Networks: Theory and Practice; John Wiley \& Sons: Hoboken, NJ, USA, 2010.

30. Akyildiz, I.F.; Vuran, M.C. Wireless Sensor Networks; John Wiley \& Sons: Hoboken, NJ, USA, 2010; Volume 4.

31. Alexander, D. The voluntary sector in emergency response and civil protection: Review and recommendations. Int. J. Emerg. Manag. 2010, 7, 151-166. [CrossRef]

32. Whittaker, J.; McLennan, B.; Handmer, J. A review of informal volunteerism in emergencies and disasters: Definition, opportunities and challenges. Int. J. Disaster Risk Reduct. 2015, 13, 358-368. [CrossRef]

33. Palen, L.; Anderson, K.M.; Mark, G.; Martin, J.; Sicker, D.; Palmer, M.; Grunwald, D. A vision for technology-mediated support for public participation \& assistance in mass emergencies \& disasters. In Proceedings of the 2010 ACM-BCS Visions of Computer Science Conference, Edinburgh, UK, 13-16 April 2010; p. 8.

34. Jaeger, P.T.; Shneiderman, B.; Fleischmann, K.R.; Preece, J.; Qu, Y.; Wu, P.F. Community response grids: E-government, social networks, and effective emergency management. Telecommun. Policy 2007, 31, 592-604. [CrossRef]

35. Poussin, J.K.; Botzen, W.W.; Aerts, J.C. Factors of influence on flood damage mitigation behaviour by households. Environ. Sci. Policy 2014, 40, 69-77. [CrossRef]

36. Poussin, J.K.; Botzen, W.W.; Aerts, J.C. Effectiveness of flood damage mitigation measures: Empirical evidence from French flood disasters. Glob. Environ. Chang. 2015, 31, 74-84. [CrossRef]

37. Bubeck, P.; Botzen, W.; Kreibich, H.; Aerts, J. Detailed insights into the influence of flood-coping appraisals on mitigation behaviour. Glob. Environ. Chang. 2013, 23, 1327-1338. [CrossRef]

38. Busch, N.E.; Givens, A.D. Achieving resilience in disaster management: The role of public-private partnerships. J. Strat. Secur. 2013, 6, 1. [CrossRef]

39. European Commission. Resource Book On PPP Case Studies; European Commission (EC) Directorate-General Regional Policy: Brussels, Belgium, 2004.

40. Cruz, C.O.; Cruz, N. Public-Private Partnership: A Framework for Private Sector Involvement in Public Infrastructure Projects. In The Governance of Infrastructure; Wegrich, K., Kostka, G., Hammerschmid, G., Eds.; Oxford University Press: Oxford, UK, 2017; p. 103.

41. Cruz, N.; Marques, R. Mixed companies and local governance: No man can serve two masters. Public Adm. 2012, 90, 737-758. [CrossRef]

42. Cruz, C.O.; Marques, R.C. Contribution to the study of PPP arrangements in airport development, management and operation. Transp. Policy 2011, 18, 392-400. [CrossRef]

43. Steijn, B.; Klijn, E.H.; Edelenbos, J. Public private partnerships: Added value by organizational form or management? Public Adm. 2011, 89, 1235-1252. [CrossRef]

44. Sharma, M.; Bindal, A. Public-Private Partnership. Int. J. Res. 2014, 1, 1270-1274.

45. Chen, J.; Chen, T.H.Y.; Vertinsky, I.; Yumagulova, L.; Park, C. Public-private partnerships for the development of disaster resilient communities. J. Conting. Crisis Manag. 2013, 21, 130-143. [CrossRef]

46. Osei-Kyei, R.; Chan, A.P. Review of studies on the Critical Success Factors for Public-Private Partnership (PPP) projects from 1990 to 2013. Int. J. Proj. Manag. 2015, 33, 1335-1346. [CrossRef]

47. Hwang, B.-G.; Zhao, X.; Gay, M.J.S. Public private partnership projects in Singapore: Factors, critical risks and preferred risk allocation from the perspective of contractors. Int. J. Proj. Manag. 2013, 31, 424-433. [CrossRef]

48. Auzzir, Z.A.; Haigh, R.P.; Amaratunga, D. Public-private partnerships (PPP) in disaster management in developing countries: A conceptual framework. Procedia Econ. Financ. 2014, 18, 807-814. [CrossRef]

49. Jamali, D.; Karam, C.; Blowfield, M. Development-Oriented Corporate Social Responsibility: Volume 1: Multinational Corporations and the Global Context; Greenleaf Publishing: Austin, TX, USA, 2015; Volume 1.

50. DeLone, W.H.; McLean, E.R. Information systems success: The quest for the dependent variable. Inf. Syst. Res. 1992, 3, 60-95. [CrossRef] 
51. Delone, W.H.; McLean, E.R. The DeLone and McLean model of information systems success: A ten-year update. J. Manag. Inf. Syst. 2003, 19, 9-30.

52. Chen, Y. The empirical analysis model on critical success factors for emergency management engineering information system. Syst. Eng. Procedia 2012, 5, 234-239. [CrossRef]

53. Lee, J.; Bharosa, N.; Yang, J.; Janssen, M.; Rao, H.R. Group value and intention to use-A study of multi-agency disaster management information systems for public safety. Decis. Support Syst. 2011, 50, 404-414. [CrossRef]

54. Petter, S.; McLean, E.R. A meta-analytic assessment of the DeLone and McLean IS success model: An examination of IS success at the individual level. Inf. Manag. 2009, 46, 159-166. [CrossRef]

55. Aldholay, A.H.; Isaac, O.; Abdullah, Z.; Ramayah, T. The role of transformational leadership as a mediating variable in DeLone and McLean information system success model: The context of online learning usage in Yemen. Telemat. Inform. 2018. [CrossRef]

56. Duggan, E.W.; Reichgelt, H. The panorama of information systems quality. In Measuring Information Systems Delivery Quality; Idea Group Pub.: Hershey, PA, USA, 2006; pp. 1-27.

57. Garrity, E.J.; Sanders, G.L. Information Systems Success Measurement; Idea Group Publ.: Hershey, PA, USA, 1998.

58. Singh, S.R. Information System Management; APH Publishing Corporation: New Delhi, India, 2007.

59. DeLone, W.H.; McLean, E.R. Information systems success measurement. Found. Trends Inf. Syst. 2016, 2, 1-116. [CrossRef]

60. Acton, T.; Halonen, R.; Conboy, K.; Golden, W. DeLone \& McLean success model as a descriptive tool in evaluating the use of a virtual learning environment. Paper Presented at International Conference on Organizational Learning, Knowledge and Capabilities (OLKC 2009), Amsterdam, The Netherlands, 26-28 April 2009; Available online: https:/ / aran.library.nuigalway.ie/handle/10379/222 (accessed on 11 June 2018).

61. Eppler, M.J. Managing Information Quality: Increasing the Value of Information in Knowledge-Intensive Products and Processes; Springer Science \& Business Media: Berlin, Germany, 2006.

62. Seppänen, H.; Virrantaus, K. Shared situational awareness and information quality in disaster management. Saf. Sci. 2015, 77, 112-122. [CrossRef]

63. Lin, H.-F. The impact of website quality dimensions on customer satisfaction in the B2C e-commerce context. Total Qual. Manag. Bus. Excell. 2007, 18, 363-378. [CrossRef]

64. Hsu, C.-L.; Chang, K.-C.; Chen, M.-C. The impact of website quality on customer satisfaction and purchase intention: Perceived playfulness and perceived flow as mediators. Inf. Syst. e-Bus. Manag. 2012, 10, 549-570. [CrossRef]

65. Pituch, K.A.; Lee, Y.-K. The influence of system characteristics on e-learning use. Comput. Educ. 2006, 47, $222-244$. [CrossRef]

66. Lin, F.; Fofanah, S.S.; Liang, D. Assessing citizen adoption of e-Government initiatives in Gambia: A validation of the technology acceptance model in information systems success. Gov. Inf. Q. 2011, 28, 271-279. [CrossRef]

67. Rogstadius, J.; Vukovic, M.; Teixeira, C.; Kostakos, V.; Karapanos, E.; Laredo, J.A. CrisisTracker: Crowdsourced social media curation for disaster awareness. IBM J. Res. Dev. 2013, 57. [CrossRef]

68. Lin, W.-S.; Wang, C.-H. Antecedences to continued intentions of adopting e-learning system in blended learning instruction: A contingency framework based on models of information system success and task-technology fit. Comput. Educ. 2012, 58, 88-99. [CrossRef]

69. Hu, X. Effectiveness of information technology in reducing corruption in China: A validation of the DeLone and McLean information systems success model. Electron. Libr. 2015, 33, 52-64.

70. Petter, S.; DeLone, W.; McLean, E. Measuring information systems success: Models, dimensions, measures, and interrelationships. Eur. J. Inf. Syst. 2008, 17, 236-263. [CrossRef]

71. Scott, M.; Golden, W. Understanding net benefits: A citizen-based perspective on e-government success. In Proceedings of the International Conference on Information Systems, ICIS 2009, Phoenix, AZ, USA, 15-18 December 2009.

72. Geddes, M. Making Public Private Partnerships Work: Building Relationships and Understanding Cultures; Gower: Wales, UK, 2005.

73. Buxbaum, J.N.; Ortiz, I.N.; Board, N.R.C.T.R.; Program, N.C.H.R.; Highway, A.A.O.S.; Officials, T.; Administration, U.S.F.H. Public Sector Decision Making for Public-Private Partnerships; Transportation Research Board: Washington, DC, USA, 2009. 
74. Ministry of Economy, F.A.D. Public Private Partnership in Burkina Faso; Ministry of Economy, Finance and Development, Burkina Faso: Ouagadougou, Burkina Faso, 2016. Available online: http:/ / www.pndes2020. com/pdf/03-en.pdf (accessed on 11 June 2018).

75. Saaty, T.L. Fundamentals of the analytic network process. In Proceedings of the 5th International Symposium on the Analytic Hierarchy Process, Kobe, Japan, 12-14 August 1999; pp. 12-14.

76. Triantaphyllou, E.; Baig, K. The impact of aggregating benefit and cost criteria in four MCDA methods. IEEE Trans. Eng. Manag. 2005, 52, 213-226. [CrossRef]

77. Opricovic, S.; Tzeng, G.-H. Compromise solution by MCDM methods: A comparative analysis of VIKOR and TOPSIS. Eur. J. Oper. Res. 2004, 156, 445-455. [CrossRef]

78. Figueira, J.R.; Greco, S.; Roy, B.; Słowiński, R. ELECTRE methods: Main features and recent developments. In Handbook of Multicriteria Analysis; Springer: New York, NY, USA, 2010; pp. 51-89.

79. Dalkey, N.; Helmer, O. An experimental application of the Delphi method to the use of experts. Manag. Sci. 1963, 9, 458-467. [CrossRef]

80. Linstone, H.A.; Turoff, M. The Delphi Method: Techniques and Applications; Addison-Wesley: Boston, MA, USA, 2002.

81. Gallego, D.; Bueno, S. Exploring the application of the Delphi method as a forecasting tool in Information Systems and Technologies research. Technol. Anal. Strat. Manag. 2014, 26, 987-999. [CrossRef]

82. Murry, J.W.; Hammons, J.O. Delphi: A versatile methodology for conducting qualitative research. Rev. High. Educ. 1995, 18, 423-436. [CrossRef]

83. Liao, S.; Wu, M.-J.; Huang, C.-Y.; Kao, Y.-S.; Lee, T.-H. Evaluating and enhancing three-dimensional printing service providers for rapid prototyping using the DEMATEL based network process and VIKOR. Math. Probl. Eng. 2014, 2014, 1-16. [CrossRef]

84. Hwang, B.-N.; Huang, C.-Y.; Wu, C.-H. A TOE approach to establish a green supply chain adoption decision model in the semiconductor industry. Sustainability 2016, 8, 168. [CrossRef]

85. Hwang, B.-N.; Huang, C.-Y.; Yang, C.-L. Determinants and their causal relationships affecting the adoption of cloud computing in science and technology institutions. Innovation 2016, 18, 164-190. [CrossRef]

86. Li, Y.; Hu, Y.; Zhang, X.; Deng, Y.; Mahadevan, S. An evidential DEMATEL method to identify critical success factors in emergency management. Appl. Soft Comput. 2014, 22, 504-510. [CrossRef]

87. Rahman, N.A.; Tarmudi, Z.; Rossdy, M.; Muhiddin, F.A. Flood Mitigation Measres Using Intuitionistic Fuzzy Dematel Method. Malays. J. Geosci. 2017. [CrossRef]

88. Fan, Z.-P.; Suo, W.-L.; Feng, B. Identifying risk factors of IT outsourcing using interdependent information: An extended DEMATEL method. Expert Syst. Appl. 2012, 39, 3832-3840. [CrossRef]

89. Tzeng, G.-H.; Huang, C.-Y. Combined DEMATEL technique with hybrid MCDM methods for creating the aspired intelligent global manufacturing \& logistics systems. Ann. Oper. Res. 2012, 197, 159-190.

90. Yang, C.-L.; Huang, C.-Y.; Kao, Y.-S.; Tasi, Y.-L. Disaster Recovery Site Evaluations and Selections for Information Systems of Academic Big Data. Eurasia J. Math. Sci. Technol. Educ. 2017, 13, 4553-4589. [CrossRef]

91. Yang, C.-L.; Yuan, B.J.; Huang, C.-Y. Key determinant derivations for information technology disaster recovery site selection by the multi-criterion decision making method. Sustainability 2015, 7, 6149-6188. [CrossRef]

92. Dilley, M. Natural Disaster Hotspots: A Global Risk Analysis; World Bank Publications: Washington, DC, USA, 2005; Volume 5.

93. World Bank. Natural Disaster Hotspots: A Global Risk Analysis Synthesis Report; The World Bank: Washington, DC, USA, 2005.

94. Tsou, C.-Y.; Feng, Z.-Y.; Chigira, M. Catastrophic landslide induced by typhoon Morakot, Shiaolin, Taiwan. Geomorphology 2011, 127, 166-178. [CrossRef]

95. Bharosa, N.; Appelman, J.; Van Zanten, B.; Zuurmond, A. Identifying and confirming information and system quality requirements for multi-agency disaster management. In Proceedings of the ISCRAM 2009 the 6th International Conference on Information Systems for Crisis Response and Management, Gothenborg, Sweden, 10-13 May 2009.

96. Nelson, R.R.; Todd, P.A.; Wixom, B.H. Antecedents of information and system quality: An empirical examination within the context of data warehousing. J. Manag. Inf. Syst. 2005, 21, 199-235. [CrossRef] 
97. Hiltz, S.R.; Plotnick, L. Dealing with information overload when using social media for emergency management: Emerging solutions. In Proceedings of the 10th International ISCRAM Conference, Baden-Baden, Germany, May 2013; pp. 823-827.

98. Johannessen, Å.; Rosemarin, A.; Thomalla, F.; Swartling, Å.G.; Stenström, T.A.; Vulturius, G. Strategies for building resilience to hazards in water, sanitation and hygiene (WASH) systems: The role of public private partnerships. Int. J. Disaster Risk Reduct. 2014, 10, 102-115. [CrossRef]

99. Muthuri, J.N.; Matten, D.; Moon, J. Employee volunteering and social capital: Contributions to corporate social responsibility. Br. J. Manag. 2009, 20, 75-89. [CrossRef]

100. Grant, A.M. Giving time, time after time: Work design and sustained employee participation in corporate volunteering. Acad. Manag. Rev. 2012, 37, 589-615. [CrossRef]

101. Hunt, M.; Davies, S.; Pittard, V. Becta Review 2006: Evidence on the Progress of ICT in Education; British Educational Communications and Technology Agency (BECTA): Coventry, UK, 2006.

102. Williams, F.A. Combustion Theory; CRC Press: Boca Raton, FL, USA, 2018.

103. Jamil, G.L.; Soares, A.L.; Pessoa, C.R.M. Handbook of Research on Information Management for Effective Logistics and Supply Chains; IGI Global: Hershey, PA, USA, 2016.

104. Lin, Y.-H.; Tsai, K.-M.; Shiang, W.-J.; Kuo, T.-C.; Tsai, C.-H. Research on using ANP to establish a performance assessment model for business intelligence systems. Expert Syst. Appl. 2009, 36, 4135-4146. [CrossRef]

105. Dreesbach-Bundy, S.; Scheck, B. Corporate volunteering: A bibliometric analysis from 1990 to 2015. Bus. Ethics Eur. Rev. 2017, 26, 240-256. [CrossRef]

106. Hahn, T.; Pinkse, J.; Preuss, L.; Figge, F. Tensions in corporate sustainability: Towards an integrative framework. J. Bus. Ethics 2015, 127, 297-316. [CrossRef]

107. Samuel, O.; Wolf, P.; Schilling, A. Corporate volunteering: Benefits and challenges for nonprofits. Nonprofit Manag. Leadersh. 2013, 24, 163-179. [CrossRef]

(C) 2018 by the authors. Licensee MDPI, Basel, Switzerland. This article is an open access article distributed under the terms and conditions of the Creative Commons Attribution (CC BY) license (http://creativecommons.org/licenses/by/4.0/). 